Review

\title{
Exogenous Contrast Agents in Photoacoustic Imaging: An In Vivo Review for Tumor Imaging
}

\author{
Afifa Farooq ${ }^{1}{ }^{(}$, Shafiya Sabah ${ }^{1}$, Salam Dhou ${ }^{1,2, * \mathbb{C}}$, Nour Alsawaftah ${ }^{1} \mathbb{D}$ and Ghaleb Husseini ${ }^{1,3, * \mathbb{C}}$ \\ 1 Biomedical Engineering Graduate Program, American University of Sharjah, \\ Sharjah 26666, United Arab Emirates; g00051241@alumni.aus.edu (A.F.); \\ g00079837@alumni.aus.edu (S.S.); nalsawaftah@aus.edu (N.A.) \\ 2 Department of Computer Science and Engineering, American University of Sharjah, \\ Sharjah 26666, United Arab Emirates \\ 3 Department of Chemical Engineering, American University of Sharjah, Sharjah 26666, United Arab Emirates \\ * Correspondence: sdhou@aus.edu (S.D.); ghusseini@aus.edu (G.H.); Tel.: +971-6-515-2943 (S.D.); \\ +971-6-515-2970 (G.H.)
}

Citation: Farooq, A.; Sabah, S.;

Dhou, S.; Alsawaftah, N.; Husseini, G.

Exogenous Contrast Agents in

Photoacoustic Imaging: An In Vivo

Review for Tumor Imaging.

Nanomaterials 2022, 12, 393.

https://doi.org/10.3390/

nano12030393

Academic Editor: Horacio Cabral

Received: 13 December 2021

Accepted: 18 January 2022

Published: 25 January 2022

Publisher's Note: MDPI stays neutral with regard to jurisdictional claims in published maps and institutional affiliations.

Copyright: (c) 2022 by the authors. Licensee MDPI, Basel, Switzerland. This article is an open access article distributed under the terms and conditions of the Creative Commons Attribution (CC BY) license (https:// creativecommons.org/licenses/by/ $4.0 /)$.

\begin{abstract}
The field of cancer theranostics has grown rapidly in the past decade and innovative 'biosmart' theranostic materials are being synthesized and studied to combat the fast growth of cancer metastases. While current state-of-the-art oncology imaging techniques have decreased mortality rates, patients still face a diminished quality of life due to treatment. Therefore, improved diagnostics are needed to define in vivo tumor growths on a molecular level to achieve image-guided therapies and tailored dosage needs. This review summarizes in vivo studies that utilize contrast agents within the field of photoacoustic imaging - a relatively new imaging modality-for tumor detection, with a special focus on imaging and transducer parameters. This paper also details the different types of contrast agents used in this novel diagnostic field, i.e., organic-based, metal/inorganic-based, and dye-based contrast agents. We conclude this review by discussing the challenges and future direction of photoacoustic imaging.
\end{abstract}

Keywords: photoacoustic imaging; exogenous contrast agents; tumor imaging

\section{Introduction}

Photoacoustic imaging (PAI) [1] is a breakthrough invention in the field of bioengineering [2]. It involves the transmission of a short pulse of laser non-invasively onto the tissues. The absorbed light changes into heat, causing the thermal excitation and expansion of the tissues. This results in generating acoustic waves that can be detected via a transducer [3]. PAI offers several advantages, including the utilization of non-ionizing radiation, the ability to reach greater depths, as well as increased resolution and optical contrast [4]. The discovery of the photoacoustic (PA) effect dates back to 1880, when the phenomenon was first observed by Alexander Graham Bell [5]. Bell reported that sound is produced upon the illumination of solid materials with a light beam. The light beam must be of a vibratory nature for the PA effect to be observed. As laser technology became available in the 1960s, the PA effect began to be considered for practical applications. By the 1990s, researchers working in the field recognized the potential use of the PA effect for medical imaging [6-9]. R. Esenaliev et al. [6] studied the feasibility of using optoacoustic laser imaging for the early detection of breast cancer. In the phantom study performed in [6], it was observed that in comparison to ultrasound (US) and mammography, the new laser optoacoustic imaging technique offers images with improved contrast for phantoms that were dense and uniform acoustically. Over time, with improvements in hybrid imaging technologies and advancements in image reconstruction algorithms, it became possible to use the PA effect for in vivo studies [10-12]. In the past few years, a significant evolution in 
PAI is evident, which will be further discussed in this paper with a focus on contrast agents used in in vivo PAI studies (refer to Figure 1).

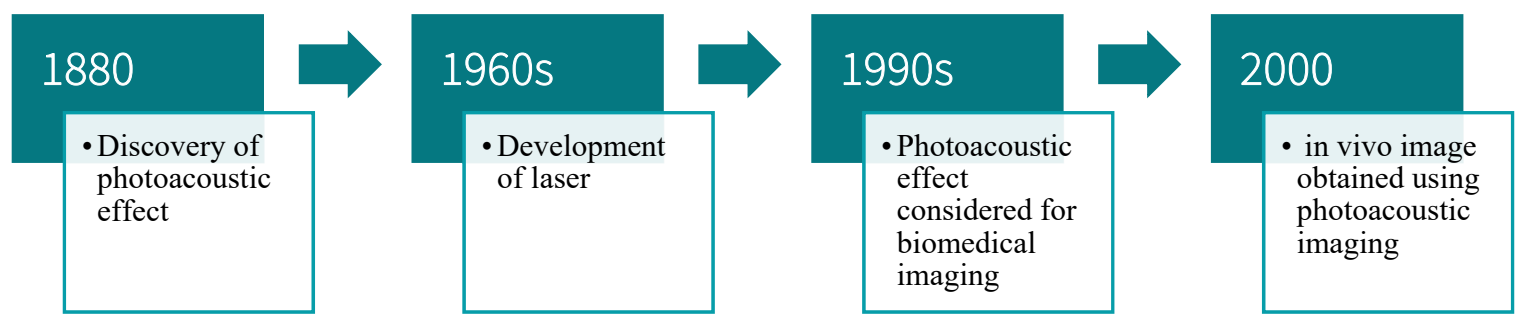

Figure 1. PAI timeline.

Materials that absorb the transmitted optical signal can be endogenous, i.e., present naturally in the body, or exogenous, i.e., synthesized/developed outside the body. In vivo studies have been performed to detect tumors using probes that can be activated by enzymes related to cancer [13], probes based on peptides [14], gold nanoparticles [15,16], dyes [17-19], melanin, oxy- and deoxy-hemoglobin [20,21]. Previous reviews have summarized methods that utilize different contrast agents. However, these publications fall short of presenting the different agents based on image quality, blood circulation time, cytotoxicity levels, and laser pulse parameters. Table 1 summarizes contrast agents used for various imaging modalities.

As PAI is a low-cost, non-invasive imaging modality that uses non-ionizing laser power for the excitation of target tissues; it can provide real-time physiological information such as blood oxygenation and other structural information of the site being studied [22]. The penetration depth offered by PAI is higher than that conventionally offered by optical imaging. Apart from providing great benefits, PAI has certain limitations. Optical fluence, i.e., the deposited optical energy on the target region through laser, is depth-dependent and can lead to lower amplitudes of the PA signal arising from deep tissues and vessels $[23,24]$. Therefore, achieving a clinically desired penetration depth with PAI is challenging, thus limiting its use in widespread medical applications. Another challenge with PAI occurs while imaging regions with overlapping tissue types as the acoustic properties between different tissue types are not consistent [25]. In addition, the safety and compatibility of exogenous contrast agents used in PAI with the biological system need to be ensured.

Due to the rising trend of imaging tumor tissues using PAI [26-34] (see Figure 2), this review summarizes the recent major developments in PAI. It summarizes the in vivo studies that utilize different contrast agents to produce an enhanced image. Furthermore, this review aims to classify these contrast agents into organic-based, metal-based, and dye-based agents with a detailed commentary on significant points of interest. The rest of the paper is organized as follows. Section 2 discussed the contrast agents used for in vivo studies. Section 3 concludes the paper and presents the challenges facing PAI along with future research directions. 


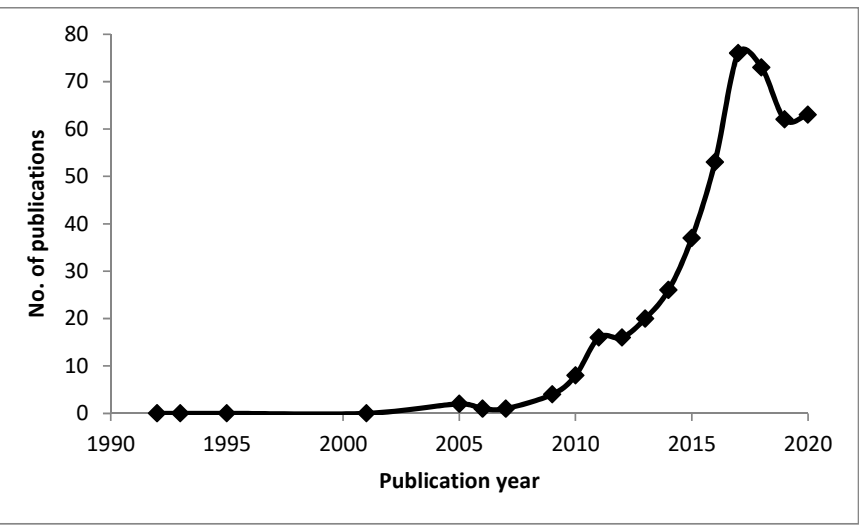

Figure 2. Emerging trend in the field of exogenous contrast agents for in vivo literature of tumors using photoacoustic imaging (Data compiled using Web of Science and ScienceDirect databases).

Table 1. Contrast agents used for different imaging modalities.

\begin{tabular}{|c|c|c|}
\hline Modality & Commonly Used Contrast Agents & References \\
\hline MRI & $\begin{array}{l}\text { Gadolinium, Super paramagnetic iron } \\
\text { oxide nanoparticles (SPIONs), Carbon-13, } \\
\text { Nanodiamonds, Carbon nanotubes, } \\
\text { Graphene, Manganese, Silicon, Peptides }\end{array}$ & [35] \\
\hline CT & $\begin{array}{c}\text { Gold nanoparticles, Iodine (131I), } \\
\text { Bismuth, Lathanide-based (gadolinium, } \\
\text { dysprosium, ytterbium) }\end{array}$ & {$[35,36]$} \\
\hline Ultrasound & $\begin{array}{l}\text { Nanobubbles, microbubbles (with } \\
\text { modifications) }\end{array}$ & {$[35,37]$} \\
\hline PET & $\begin{array}{l}\text { Gold nanoparticles, Copper }(64 \mathrm{Cu}) \text {, } \\
\text { Iodine (124I), Fluorine }(18 \mathrm{~F})\end{array}$ & {$[35,38]$} \\
\hline SPECT & Gold nanoparticles, Technetium (99mTc) & [35] \\
\hline Optical Imaging & $\begin{array}{c}\text { Fluorescence, Quantum dots, Gold } \\
\text { nanoparticles, Persistent luminescence } \\
\text { nanoparticles }\end{array}$ & [35] \\
\hline \multicolumn{2}{|c|}{$\begin{array}{c}\text { Combinations of these contrast agents can be used to create hybrid contrast agents and } \\
\text { optimize imaging }\end{array}$} & {$[38,39]$} \\
\hline
\end{tabular}

\section{Contrast Agents for In Vivo Testing}

\subsection{Basis of PAI and Design Considerations for Contrast Agents}

PAI is based on PA tomography (PAT) that incorporates optical imaging and US. A short pulse of laser is transmitted onto/into the tissues non-invasively. The absorbed light changes into heat, causing the thermal excitation and expansion of tissues [40]. This results in generating acoustic waves that can be detected via a transducer. One of the principal subdivisions in PAT is photoacoustic microscopy (PAM). In PAM, every excitation by a laser pulse creates an image in one dimension of a point in the object. Numerous one-dimension images can be combined to form a three-dimension image without using reconstruction algorithms [3].

Endogenous and exogenous contrast agents are used in PAI. Endogenous molecules found in the body, such as melanin and hemoglobin, have broad optical absorption in the visible light and near-infrared (NIR) ranges compared to adjacent tissues, leading to strong PA contrast signals. However, information obtained by imaging a tumor in its initial phase using endogenous contrast agents is not adequate; hence, biocompatible exogenous contrast agents are used. The latter provides an enhanced signal contrast and better image quality compared to endogenous contrast agents [41]. 
Contrast agents in PAI are usually chosen to optimize absorption and depth in vivo. For this reason, contrast agent wavelengths should be in the NIR range. There is minimal light absorption in this region by hemoglobin above $650 \mathrm{~nm}$, and by water below $900 \mathrm{~nm}$ [42]. More recently, the NIR-II window, in the 1000-1700 nm range, is a focus of contrast agent development as it has a greater tissue penetration depth due to lower lighttissue interaction and safe use of higher power density for light irradiation [43]. Longer penetration depth and higher contrast provided by NIR-II window compared to NIR-I window are because of reduced tissue scattering and minimal tissue absorption [44]. In short, minimal absorption means more significant penetration depths. Some of the major factors that must be taken into consideration to optimize imaging in vivo are: (1) Having long blood circulation times, i.e., these agents or nanoparticles should be able to evade the immune response by the reticuloendothelial system (RES) cells, travel across membrane barriers, and avoid elimination by renal and splenic filtration and reach the imaged tissue, (2) Being biocompatible, i.e., not cytotoxic within the concentration dosage to be administered for imaging, (3) Exhibiting a strong imaging signal to improve poor contrast, (4) Possessing biological specificity, i.e., being designed such that it can reach the imaged area in a reasonable time frame [42].

Since this review will mainly focus on imaging cancer malignancies, it is necessary to mention the three methods of tumor targeting in oncology: passive, active, and triggered targeting. Passive targeting involves the utilization of the enhanced permeability and retention (EPR) phenomenon, which increases the accumulation of nanoparticles (in the size range of 15-150 $\mathrm{nm}$ ) at the tumor site [45]. This accumulation occurs due to the presence of underdeveloped blood vessels at tumor sites, with fenestrations and haphazard blood flow. Furthermore, due to the fast-growing nature of cancerous tissue, there are few to no lymphatic vessels, and thus, low drainage allows a 10-50 times higher accumulation than healthy tissues [46]. As mentioned earlier, several factors should be taken into consideration when designing these nanocarriers. The optimal size, $10-150 \mathrm{~nm}$, is an essential factor to avoid filtration by the kidneys, and/or uptake by the liver- unless the region of interest includes these organs [45]. Active- or ligand- targeting uses receptor-mediated endocytosis to internalize nanocarriers. The surface of these drug encapsulating vehicles is decorated with targeting moieties (e.g., folic acid, estrone, Herceptin, etc.) that direct the probe to receptors overexpressed on the surface of the cancer cells. Triggered targeting can be achieved using internal and external means. Internal triggers include temperature, enzyme concentration, and $\mathrm{pH}$ levels, while external stimuli include US, NIR, and electromagnetic waves. As the performance of PAI is dependent on optically absorbing components within synthesized nanostructures, a combination of these components generally leads to better results. Therefore, this paper aims to broadly classify these multimodal/hybrid nanoagents based on component materials with PA functionality (while other components in the nanoagents perform either therapeutic, other imaging types or biocompatibility functions).

\subsection{Organic Contrast Agents}

Since each class of materials has specific advantages for different applications, the key advantage of organic contrast agents is that they are non-toxic and can degrade in living bodies. Nanosystems are the focus of current diagnostic, theranostic and drug delivery research due to the versatility of these materials. They are increasingly combined with organics nanoparticles and biodegradable polymers to build a new generation of contrast agents that enhance specific parameters. In addition, their size, shape, mechanical flexibility and surface chemistry can be modified to optimize their efficacy in clinical applications [47-49]. Due to their in vivo high biocompatibility, fluorescent nature, and modification flexibility, Xiao et al. [50] synthesized and characterized melanin carbonaceous dots (MCDs) for dual PAI and fluorescence imaging of breast cancer tumors in mice. With MCDs having an absorbance peak at $633 \mathrm{~nm}$, near the infrared lower wavelength limit of $700 \mathrm{~nm}$, higher spatial resolution imaging was produced for higher penetration depths. MCDs, for PAI, were combined with fluorescent imaging to improve the low 
spatial resolution of the latter. The major advantages of MCDs are their (1) prolonged blood circulation time, and (2) in vivo accumulation in triple-negative breast cancer (4T1) xenografts. However, more work is needed before these probes proceed to clinical trials, as their overall toxicity was high. In addition to tumors, they also accumulated heavily in the liver and kidneys and can therefore, be used to image both organs.

However, due to the tedious, costly, and complex synthesis of carbon dots (CDs), research groups have been extracting/deriving these CDs from natural resources such as Hypocrella bambusae (a parasitic fungus) [51], ethylene diamine, phosphoric acid and citric acid [52], and polythiophene phenylpropionic acid (refer to Figure 3) [53]. The enzyme horseradish peroxidase, derived from horseradish roots, was also used in conjunction with 2,2'-azino-bis(3-ethylbenzothiazoline-6-sulfonic acid) (ABTS) and encapsulated in liposomes to act as an $\mathrm{H}_{2} \mathrm{O}_{2}$-responsive in vivo nanoprobe [54]. The idea behind these nanoprobes is that they will react directly with the targeted molecule and thus, exhibit high specificity to the desired molecule.

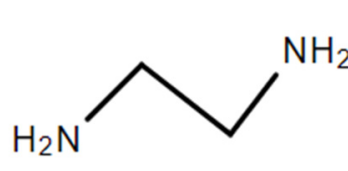

Ethylene Diamine

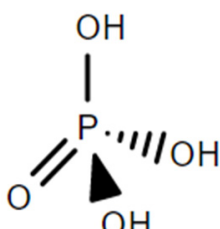

Phosphoric Acid<smiles>O=C(O)CC(O)(CC(=O)O)C(=O)O</smiles>

Citric Acid<smiles>O=C(O)CCc1ccccc1</smiles>

Phenylpropionic Acid

Figure 3. Chemical structures of natural sources for CDs' production.

The nanoprobes mentioned above were used in cancer theranostics to detect $\mathrm{H}_{2} \mathrm{O}_{2}$ levels via the following method: synthesized glucose oxidase PEGylated (polyethylene glycol, PEG) liposomes, for starvation therapy in a 4T1-tumor microenvironment, were metabolized by the cancer cells to form gluconic acid and $\mathrm{H}_{2} \mathrm{O}_{2}$. The synthesized nanoprobe then detected the $\mathrm{H}_{2} \mathrm{O}_{2}$, thus, implementing an innovative theranostic strategy [55].

Since a major branch of theranostics in cancer nanomedicine deals with lipids for drug encapsulation, contrast agent encapsulation, ligand targeting, and biocompatibility coating, it is necessary to discuss polymeric nanoparticles and their role as contrast agents in PAI. Here it becomes essential to remind the reader that lipids exhibit optical absorbance but to a lesser extent compared to other endogenous contrast agents. Consequently, Liu et al. [56] synthesized two novel triblock copolymer nanosystems, poly(2-methyl-2-oxazoline)-blockpoly (dimethylsiloxane)-block-poly(2-methyl-2-oxazoline) (PMOXA-b-PDMS-b-PMOXA); one with positively-charged terminal amino acid groups (P-NPs) and the other with negatively-charged terminal carboxylic groups (N-NPs). These micelles, spherical selfassembling single-layered nanocarriers with a hydrophobic core, were used to encapsulate a hydrophobic NIR photonic agent called hydrophobized phthalocyanine Zinc complex (H-PcZn) and the absorbance peak of both nanosystems was measured to be $680 \mathrm{~nm}$-note that this is within the NIR window. A linear increase in the intensity of the PA signal was also observed with a logarithmic increase in the concentration of both P-NPs and N-NPs. The PA signal plateaued within $10 \mathrm{~min}$ of in vivo administration in mice, with an increased accumulation observed in the spleen compared to the liver and kidneys for N-NPs, whereas P-NPs exhibited increased accumulation in both the liver and spleen as compared to the kidneys and a comparatively stronger signal (by a factor of 1.5 in the spleen) in other tissues. Therefore, this signifies that organ-specific applications for each nanosystem can be developed. Still, longer incubation times are required to measure blood circulation times and the use of targeting moieties for specific tissues and tumors to enhance tumor targeting abilities [56,57] (see Table 2). In general, the advantage of using conjugated polymers, aside from their NIR absorbance/emission for PAI and photothermal therapy, is the ability to modify side chains to achieve desired characteristics such as self-assembly, increased protein corona formation for better nanoparticle biodistribution and targeted applications 
with the band gap in their $\pi-\pi^{*}$ electronic transition influencing emitted spectra and leading to tunable optical properties [58,59].

Table 2. Detailed Parameters for Contrast Agent Studies.

\begin{tabular}{|c|c|c|c|c|}
\hline Material & MCDs [50] & P-NP and N-NPs [56] & $\begin{array}{l}\text { PGNR-PT6 and } \\
\text { PGNR-PT7 [14] }\end{array}$ & MAGE-Au-PFH-NP [15] \\
\hline Purpose & $\begin{array}{l}\text { In vivo breast cancer } \\
\text { imaging in mice }\end{array}$ & $\begin{array}{l}\text { In vivo organ imaging in } \\
\text { mice }\end{array}$ & $\begin{array}{l}\text { In vivo osteosarcoma } \\
\text { cancer imaging in mice }\end{array}$ & $\begin{array}{c}\text { In vivo melanoma-tumor } \\
\text { imaging in mice }\end{array}$ \\
\hline No. of array elements & $\begin{array}{l}128 \text { with a circular arc of } \\
270^{\circ} \text { from } 680 \text { to } 900 \mathrm{~nm}\end{array}$ & $\begin{array}{l}256 \text { with a circular arc of } \\
270^{\circ}\end{array}$ & - & \\
\hline Pulse duration (ns) & 10 & 10 & - & \\
\hline Repetition rate $(\mathrm{Hz})$ & 10 & 10 & - & \\
\hline Central frequency $(\mathrm{MHz})$ & 5 & 5 & - & 21 \\
\hline Average size (nm) & 40 & $\begin{array}{c}20 \text { for P-NP, and } 100 \text { for } \\
\text { N-NP }\end{array}$ & $\begin{array}{c}81.7 \text { for PGNR-PT6, and } \\
82.7 \text { for PGNR-PT7 }\end{array}$ & 354.27 \\
\hline Contrast & High & High & $\begin{array}{c}\text { PGNR-PT6 and } \\
\text { PGNR-PT7 enhanced } \\
\text { contrast by } 170 \% \text { and } \\
230 \% \text {, respectively }\end{array}$ & High \\
\hline Bio distribution (hours) & 24 & 1 (more work needed) & 24 & 24 \\
\hline $\begin{array}{c}\text { Peak time } \\
\text { (@Concentrationmax) } \\
\text { (hours) }\end{array}$ & 2 & 0.2 & 4 & 2 \\
\hline Biosafety & Low & Not measured & High & High \\
\hline Physical efficacy & High & High & Very High & High \\
\hline
\end{tabular}

A problem associated with using US transducers is signal intensity loss due to US transducers having limited frequency range detection; therefore, a study by Kim et al. [60] used porphyrin phospholipid microbubble to produce resonance-based frequency-selective PA signals. Porhyrin, and other small-molecule organic dyes such as cyanine and squaraine, are being used increasingly due to their flexibility for structural modification and faster clearance with porphyrin being used as contrast and phase-change from nanodroplets to microbubbles for both ultrasound and PAI [61,62]. Theranostic molecular engineered dyes such as heptacyclic B, O-chelated BODIPY organic molecules have also demonstrated 14 times enhancement in PAI contrast post $10 \mathrm{~h}$ injection along with $58.7 \%$ photothermal conversion for hyperthermic tumor ablation [63]. Development of self-assembling $\mathrm{pH}-$ sensitive charge-transfer nanocomplexes by $3,3^{\prime}, 5,5^{\prime}$-tetramethylbenzidine within the NIR-II window has shown good contrast up to $5 \mathrm{~cm}$ and can be further investigated for NIR-II PA contrast agents [64]. Similarly, Pu et al. [65] used the electronic and optical properties of semiconducting oligomers and BODIPY dyes. The former acted as a PA matrix and the latter acted as PA signal enhancer and $\mathrm{pH}$ indicator for improved ratiometric response and increased $\mathrm{pH}$ sensitivity. Another study used oligomerization to its advantage for PA signal modulation based on intramolecular interactions [66]. Recent reviews summarizing studies on organic contrast agents and their future trends demonstrate a greater shift towards contrast agents in the NIR-II window [33,67]. Further studies were detailed in Table 3 with additional studies found in [68-91]. 
Table 3. Classification and Summary of Tumor-Targeting In Vivo Studies for PAI Organic Nanoparticles/ Nanosystems Contrast Agents.

\begin{tabular}{|c|c|c|c|c|c|c|c|c|}
\hline Classification & Material Used & $\begin{array}{c}\text { Imaging } \\
\text { Modalities }\end{array}$ & Application & Studies Conducted & $\begin{array}{l}\text { Relevant Measured } \\
\text { Parameters }\end{array}$ & Transducer Used & $\begin{array}{c}\text { Computational } \\
\text { Techniques }\end{array}$ & $\begin{array}{c}\text { Publication } \\
\text { Year/Reference }\end{array}$ \\
\hline $\begin{array}{l}\text { Semiconducting } \\
\text { Polymer }\end{array}$ & $\begin{array}{c}\text { poly\{3-(5-(9-hexyl9- } \\
\text { octyl-9H-fluoren-2- } \\
\text { yl)thiophen-2-yl)-2,5- } \\
\text { bis(2-hexyldecyl)-6- } \\
\text { (thiophen-2-yl)pyrrolo } \\
\text { [3,4-c]pyrrole- } \\
\text { 1,4(2H,5H)-dione\} } \\
\text { (PDPPF, SP0) with SP5 } \\
\text { and SP10 (self-quenching } \\
\text { SPs) }\end{array}$ & PAI & $\begin{array}{l}\text { Imaging of breast } \\
\text { cancer and cervical } \\
\text { cancer tumors }\end{array}$ & $\begin{array}{l}\text { HeLa cervical } \\
\text { adenocarcinoma } \\
\text { epithelial cells for } \\
\text { In vitro; In vivo and } \\
\text { ex vivo on } 4 \mathrm{~T} 1 \text { breast } \\
\text { cancer tumor in } \\
\text { mice/mice organs }\end{array}$ & $\begin{array}{l}\text { Maximum PA signal } \\
\text { of SP10 at 4h for both } \\
\text { SP10-RGD and SP10 } \\
\text { with slower } \\
\text { clearance rate for } \\
\text { SP10-RGD and } 1.78 \\
\text { fold higher PA } \\
\text { intensity for } \\
\text { SP10-RGD as well }\end{array}$ & $\begin{array}{c}\text { LAZR instrument } \\
\text { (Visualsonics, } 2100 \\
\text { High-Resolution } \\
\text { Imaging System) }\end{array}$ & - & 2017 [92] \\
\hline \multirow[t]{2}{*}{$\begin{array}{l}\text { Derived from natural } \\
\text { resources }\end{array}$} & $\begin{array}{c}\text { DPAHB nanovesicles } \\
\text { (hypocrellin B (HB) } \\
\text { modified with } \\
\text { 1,2-diamino-2-methyl } \\
\text { propane encapsulated by } \\
\text { PLGA-PEG) }\end{array}$ & $\begin{array}{c}\text { PAI, } \\
\text { fluorescence, } \\
\text { photodynamic } \\
\text { and } \\
\text { photothermal } \\
\text { therapy }\end{array}$ & $\begin{array}{l}\text { Imaging of } 4 \mathrm{~T} 1 \\
\text { breast cancer tumors }\end{array}$ & $\begin{array}{c}\text { In vitro and in vivo } \\
\text { PAI. }\end{array}$ & $\begin{array}{l}\text { High-intensity } \\
\text { signals and } \\
\text { enhanced spatial } \\
\text { resolution was } \\
\text { achieved using } \\
\text { DPAHB nanovesicles. } \\
\text { PA signal intensity } \\
\text { attained maximum } \\
\text { peak at } 12 \mathrm{~h} \text { after } \\
\text { injection of } \\
\text { nanovesicles. }\end{array}$ & $\begin{array}{l}\text { MSOT inVision } 128 \\
\text { PAT system }\end{array}$ & & 2018 [93] \\
\hline & Other & & & & & & & $\begin{array}{c}2018[51] \\
2017[52,54] 2015[53]\end{array}$ \\
\hline Carbon nanodots & $\begin{array}{l}\text { Nitrogen-Doped Carbon } \\
\text { Nanodots }\end{array}$ & PAI & $\begin{array}{l}\text { Imaging of sentinel } \\
\text { lymph node to detect } \\
\text { metastatic cancer }\end{array}$ & $\begin{array}{l}\text { In vivo and ex vivo } \\
\text { mapping of sentinel } \\
\text { lymph node, in vivo } \\
\text { PAI of the bladder. }\end{array}$ & $\begin{array}{l}\text { Post injecting } \\
\text { N-CNDs PA signal } \\
\text { reached a peak at } 30 \\
\text { min, and the signal } \\
\text { kept decreasing until } \\
180 \text { min. Results } \\
\text { show that the } \\
\text { contrast agent was } \\
\text { circulating in the } \\
\text { lymphatic system } \\
\text { before being } \\
\text { degraded. }\end{array}$ & $\begin{array}{l}\text { Ultrasound } \\
\text { transducer with } \\
\text { spherical focusing } \\
\text { and having a 5-MHz } \\
\text { central frequency, } \\
\text { Acoustic-resolution } \\
\text { reflection-mode PA } \\
\text { imaging system }\end{array}$ & $\begin{array}{l}\text { Raster scanning to } \\
\text { acquire PA images }\end{array}$ & 2016 [94] \\
\hline
\end{tabular}


Table 3. Cont.

\begin{tabular}{|c|c|c|c|c|c|c|c|c|}
\hline Classification & Material Used & $\begin{array}{l}\text { Imaging } \\
\text { Modalities }\end{array}$ & Application & Studies Conducted & $\begin{array}{l}\text { Relevant Measured } \\
\text { Parameters }\end{array}$ & Transducer Used & $\begin{array}{c}\text { Computational } \\
\text { Techniques }\end{array}$ & $\begin{array}{c}\text { Publication } \\
\text { Year/Reference }\end{array}$ \\
\hline $\begin{array}{l}\text { Organic small } \\
\text { molecule }\end{array}$ & $\begin{array}{l}\text { Diradicaloid molecular } \\
\text { (DRM) structure }\end{array}$ & PAI and PTT & $\begin{array}{l}\text { Imaging of A549 } \\
\text { lung cancer }\end{array}$ & $\begin{array}{l}\text { PAI-guided PTT } \\
\text { in vitro and in vivo }\end{array}$ & $\begin{array}{l}\text { The average PA } \\
\text { signal of tumors } \\
\text { excised from the } \\
\text { mice injected with } \\
\text { DRM NPs is over } 4 \\
\text { times higher than } \\
\text { that from the control } \\
\text { group }\end{array}$ & $\begin{array}{c}\text { Vevo LAZR-X } \\
\text { imaging equipment }\end{array}$ & $\begin{array}{l}\text { DFT calculations of } \\
\text { optimized } \\
\text { geometries of the } \\
\text { DRM in the ground } \\
\text { and excited states }\end{array}$ & 2021 [95] \\
\hline Carbon nanohorns & $\begin{array}{l}\text { carbon nanohorn- } \\
\text { polyglycerol-gold } \\
\text { (CNH-PG-Au) NPs }\end{array}$ & $\mathrm{PAI}$ and $\mathrm{x}$-ray & $\begin{array}{c}\text { Imaging of } 4 \mathrm{~T} 1 \\
\text { mouse breast cancer } \\
\text { cells }\end{array}$ & $\begin{array}{l}\text { In vivo PAI of tumor } \\
\text { treatment using } \\
\text { DOX@CNH-PG-Au }\end{array}$ & $\begin{array}{l}\text { The photoacoustic } \\
\text { intensity of the } \\
\text { tumor site increased } \\
\text { gradually and } \\
\text { reached a maximum } \\
48 \text { h post-injection } \\
\text { (735 } \pm 47), \\
\text { indicating that } \\
\text { DOX@CNH-PG-Au } \\
\text { NPs steadily } \\
\text { accumulated in the } \\
\text { tumor during this } \\
\text { period }\end{array}$ & $\begin{array}{l}\text { MSOT inVision } 256 \\
\text { PAI systems }\end{array}$ & - & 2021 [97] \\
\hline $\begin{array}{l}\text { Laponite (LAP) } \\
\text { nanoplatforms }\end{array}$ & $\begin{array}{l}\text { polydopamine (PDA) } \\
\text { coated LAP } \\
\text { nanoplatforms modified } \\
\text { with polyethylene glycol- } \\
\text { arginine-glycine-aspartic } \\
\text { acid (PEG-RGD) }\end{array}$ & PAI & $\begin{array}{l}\text { Imaging of } 4 \mathrm{~T} 1 \\
\text { mouse breast cancer } \\
\text { cells }\end{array}$ & $\begin{array}{l}\text { In vitro and in vivo } \\
\text { PAI-guided chemo- } \\
\text { phototherapy of } \\
\text { cancer cells }\end{array}$ & $\begin{array}{l}\text { NPs showed an } \\
\text { increased PA signal } \\
\text { at tumor sites after } \\
\text { injection, and the PA } \\
\text { signal peaked at } 2 \mathrm{~h} \\
\text { post-injection. }\end{array}$ & $\begin{array}{c}\text { Vevo LAZR PAI } \\
\text { system equipped } \\
\text { with an } 875 \mathrm{~nm} \text { laser }\end{array}$ & - & $2021[98]$ \\
\hline
\end{tabular}




\subsection{Metal/Inorganic Contrast Agents}

Metals such as gold and silver significantly enhance contrast in PAI as their optical absorbance is based on surface plasmon resonance (SPR). Therefore, these structures exhibit higher absorbance than other optical agents such as dyes [26]. Metallic agents can also serve as contrast agents in multiple imaging modalities, and so can inorganic nanoparticles. There is increasing interest in using inorganic contrast agents as desirable properties such as tunable peaks in the NIR regions, better brightness, superior photostability, and magnetic and optical scattering and absorption, along with luminescence, renders them useful for multimodal imaging purposes [99]. Ma et al. [14] also synthesized a biocompatible nanosystem that conjugated PEGylated gold nanorods to oligopeptides PT6 and PT7, termed PGNR-PT6 and PGNR-PT7, respectively. These actively targeted nanosystems exhibited an absorbance peak at $810 \mathrm{~nm}$ and a high specificity towards osteosarcoma in UMR-106 tumor-bearing mice. Furthermore, a remarkable 2.6- and 3.4-fold contrast from PGNR-PT6 and PGNR-PT7, respectively, was found compared to a PBS-administered control group. Due to the reasons mentioned above and their low cytotoxicity, these nanorods have a strong potential for osteosarcoma-PAI applications. Another study conducted by Li et al. [15] incorporated a liquid perfluorocarbon (perfluorinated hexane/PFH), used as a contrast agent in cancer biomedicine, and gold nanorods, used in PAI due to its strong light absorption in the NIR window, with the nanoemulsion encapsulated in a poly(lactide-co-glycolide) (PLGA) shell. This highly biocompatible shell was then conjugated to a monoclonal MAGE-1 antibody to target melanoma cancer therapy specifically by binding to melanoma antigens. This nanosystem (MAGE-Au-PFH-NP) can be used in dual-modality contrast agents for PA and US imaging. With an encapsulation efficiency of $70.61 \%$, the MAGE-Au-PFH-NPs showed an enhanced PA signal and a linear increase in absorption intensity and concentration. In vivo experiments using melanoma-bearing mice demonstrated peak PA signals after $2 \mathrm{~h}$ of injection and a liquid-gas phase transformation after laser irradiation to form microbubbles, functioning as efficient US contrast agents, with a final temperature increase to $70{ }^{\circ} \mathrm{C}$ (of the gold nanorods), leading to a PFH phase change. The US signals reached peak values $10 \mathrm{~min}$ after laser irradiation and therefore, this nanosystem is a suitable contrast and treatment agent for melanomas. While gold-based contrast agents are a popular choice in PAs, it has several drawbacks, including photoinstability and difficulty in synthesis at the nanoscale [100].

Due to the high optical absorption coefficient of blood in the NIR window, researchers explored the use of magnetic nanoparticles (MNPs) as PA contrast agents, where the magnets' motion directly influences signal intensity, leading to high contrast images with suppressed images background signals [100,101]. Chau et al. [102] reviewed magnetic molecular imaging and targeting for carbon nanomaterials. They reported that prior to 2015, researchers were functionalizing carbon nanotubes, plated with gold, with proteins for targeting and iron oxide cores for magnetic manipulation. Yang et al. [103] employed the magnetic properties of metals for the trimodal imaging (PET/MRI/PAI) of tumor tissue. Apoferritin, an unloaded natural iron protein with a cage-like structure and transferrin receptor 1 (TfR1) targeting ability, was loaded with melanin nanoparticles (AMF), 64Cu2+ and Fe3+ to image HT29, high TfR1 expression, and HepG2, low TfR1 expression, in tumor-bearing mice. Not only were AMF NPs found to be well suited to the PET and MRI imaging modalities, but the PA signal was twice that of the controls used in the HT29 mice model. Due to the low TfR1 expression in the HEPG2 mice models, there was no obvious contrast observed. To enable the clinical translation of MNPs to the field of PAI Li et al. [100] not only synthesized a MNP with a functionalized folic acid PEGylated polypyrrole (PPy) shell by polymerizing PPy on the MNP surface to target cervical tumors in a mouse model, but also developed a second-generation magento-motive PAI (mmPAI) system to reduce background noise produced from static and moving tissue incorporating cyclic magnetic motion and US speckle tracking (see Figure 4). A major point of interest in this study was that since conventional PAI cannot easily distinguish a tumor unless there is already prior knowledge of the tumor location, mmPAI was employed to improve 
the contrast by two orders of magnitude compared to conventional PA images. This imaging technique can detect 100 to 100,000 tumor cells, whereas current technology has the ability to detect tumor sizes in the $\mathrm{mm}^{3}$ to $\mathrm{cm}^{3}$ range [100]. Other groups such as Wu et al. [104] and Chang et al. [105] have also utilized the magnetic properties of metals, gadolinium/bismuth, and manganese tungsten oxide, respectively, to provide simultaneous multimodal imaging and therapy for oncological purposes (see Table 2). Additionally, studies using low-frequency range PAI to track metallic nanoparticles and their aggregates, in this case, silver nanoparticles and zinc oxide, are available and can be further used to monitor individual scattering and absorption, specifically in the presence of multiple contrast agents $[106,107]$.

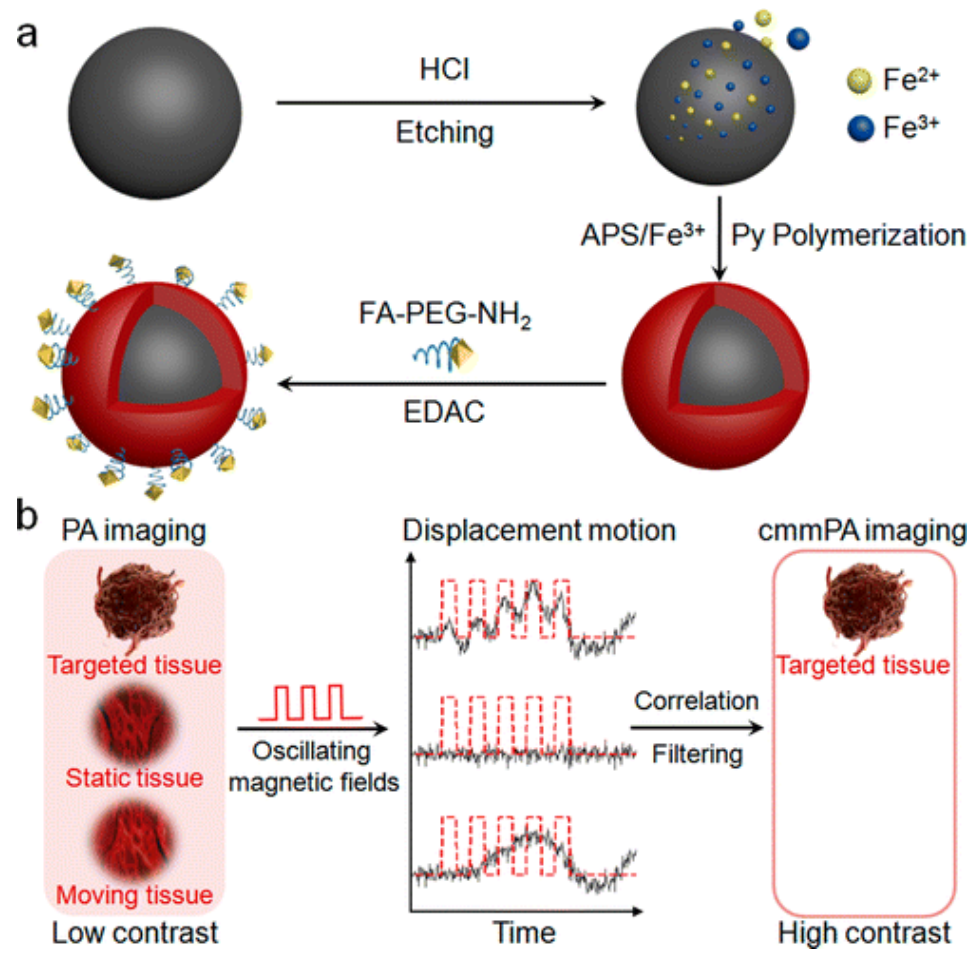

Figure 4. (a) Synthesis of MNP-PPy shell, a magneto-motive nanoparticle used for magnetic motion and speckle tracking (b) Distinctive displacement motion using magnetic fields created with synthesized magnetic nanoparticles within targeted tissue to eliminate PA background signal from non-ROI tissue [100].

The advent of theranostics, the combination of diagnostics and therapeutics, led to the development of several nanoparticles that functioned both as multimodal imaging agents and had a therapeutic function. Hence, novel nanosystems, based on previously wellresearched agents, were resynthesized, incorporating desirable characteristics to produce optimal nanosystems suitable for theranostics. Challenges such as complex synthesis routes, decreased biocompatibility, and high instability became an issue [108]. Gold nanoparticles, among the most widely researched and promising exogenous contrast agents [109], were synthesized as gold nanoclusters with strands of polyallylamine and their surfacefunctionalized with bovine serum albumin (BSA) to serve as diagnostic in vivo PA contrast agents as well as hyperthermic-anticancer agents-for $4 \mathrm{~T} 1$ tumor-bearing mice [110]. A study using ultra-small $\mathrm{Cu}_{2} \mathrm{ZnSnS}_{4}$ (CZTS) nanocrystals functionalized with BSA combined the high NIR photothermal ability of the crystals to simultaneous provide photothermal therapy (PTT), along with dual PA/MRI for in vivo $\mathrm{H} 22$ liver tumor-bearing mice where the accumulation of the nanosystem and therefore, the signal intensity was found adequate for image-guided tumor therapy [108]. Antimony (Sb) was mentioned by Li et al. [111] as a potential contrast agent in the field of PAI, and it was further researched by Hou et al. [112] by preparing an oleylamine coated Copper-Antimony-Sulfur (Cu-Sb-S) nanoparticle func- 
tionalized with poly(vinylpyrrolidone) (PVP) to act as a PA contrast agent and for use in PTT/photodynamic therapy (PDT). Hong et al. [113] demonstrated that PEGylated melanin dots loaded with gadolinium could serve as effective tumor contrast agents in MRI, and later the same group investigated this agent in vivo [114]. Additional studies were conducted in [75-77,79,110,115-122] (2018), [114,123-126] (2017), [127-133] (2016), [111,134-136] (2015) with further detailed studies summarized and classified in Table 4 . In addition, Figure 5 depicts an example of the role contrast agents play in indicating tumor sites.

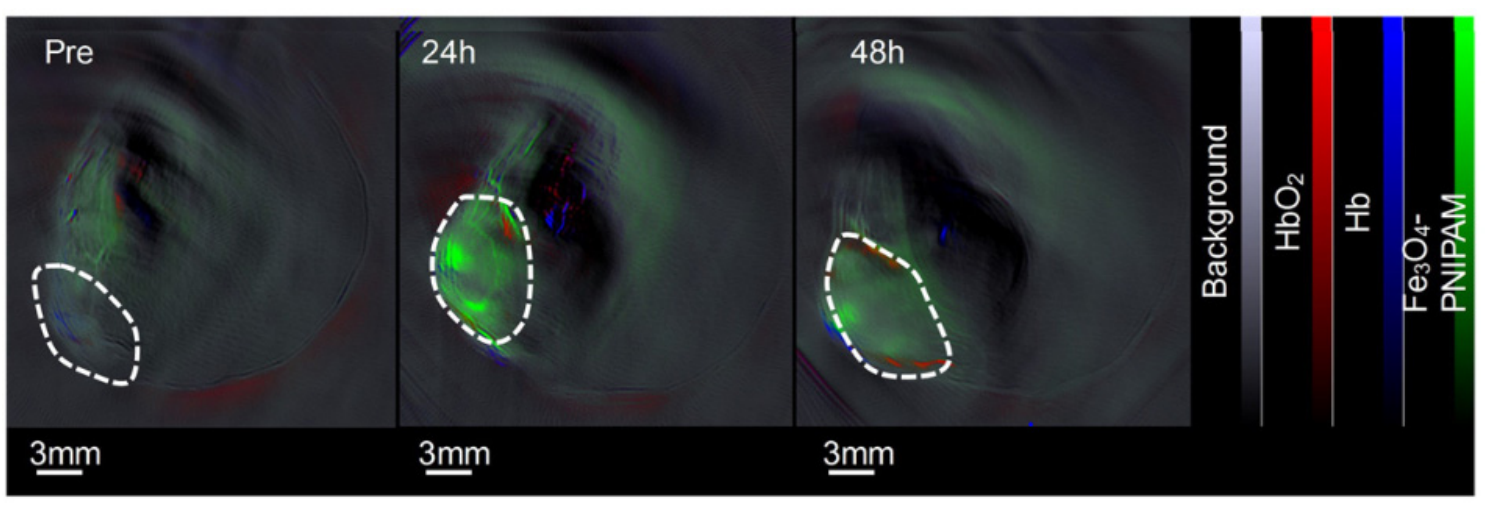

Figure 5. An example of the role contrast agents play in indicating tumor sites, with red representing oxyhemoglobin, blue representing deoxy-hemoglobin, and blue and green representing contrast agents [116].

\subsection{Dye-Based Contrast Agents}

Studies have shown the ability of some exogenous dyes to absorb NIR light and produce high-intensity PA signals leading to enhanced image contrast $[74,115,137,138]$ (2018); [85,139-141] (2017); [142-147] (2016); [80,88,148-153] (2015). One of the most commonly used dyes is indocyanine green (ICG) that is FDA approved. ICG is typically used in combination with other materials to attain a maximum PA signal. G. Wang et al. [142] used a nanocomplex consisting of hyaluronic acid and ICG enclosed within a nanotube of carbon to detect squamous cell carcinoma in mice. J. Chen et al. [143] detected Hela xenografts in mice using contrast agents made of ICG, polyethylene and nano-graphene oxide. The results showed that the composite could target the tumor passively and had a prolonged circulation time. Gao et al. [144] combined ICG with superparamagetic iron oxide for the in vivo detection of tumor imaging brain vasculature. In addition to ICG, other dyes such as NIR dyes (IR-825) [85,148], the black hole quencher (BHQ) dye [139], and DiR fluorescent dyes [145] have been used extensively for PAI. A detailed description of dye-based contrast agents and their application are listed in Table 5. 
Table 4. Classification and Summary of Tumor-Targeting In Vivo Studies for PAI Metal-based/ Inorganic Contrast Agents.

\begin{tabular}{|c|c|c|c|c|c|c|c|c|}
\hline Classification & Material Used & Imaging Modalities & Application & Studies Conducted & $\begin{array}{l}\text { Relevant Measured } \\
\text { Parameters }\end{array}$ & Transducer Used & $\begin{array}{c}\text { Computational } \\
\text { Techniques }\end{array}$ & $\begin{array}{c}\text { Publication } \\
\text { Year/Reference }\end{array}$ \\
\hline \multirow{4}{*}{$\begin{array}{l}\text { Gold nanorods } \\
\text { (AuNR)-based }\end{array}$} & AuNR & PAI & $\begin{array}{l}\text { Imaging of lymph } \\
\text { vessels/nodes in } \\
\text { breast cancer tumors }\end{array}$ & $\begin{array}{c}\text { Phantom using PTFE } \\
\text { tubes; in vivo on } \\
\text { mice }\end{array}$ & $\begin{array}{c}\text { Attenuation } \\
\text { coefficient: } \\
-1.90 \mathrm{~dB} / \mathrm{mm} \\
380 \text { times as } \\
\text { compared ICG }\end{array}$ & $\begin{array}{c}\text { Concave } \\
\text { poly(vinylidene fluo- } \\
\text { ride/trifluoroethylene) } \\
\text { (P(VDF-TrFE)) US } \\
\text { transducer }\end{array}$ & $\begin{array}{l}\text { Delay-and-sum } \\
\text { (DAS) beamforming } \\
\text { method }\end{array}$ & 2018 [154] \\
\hline & $\begin{array}{c}{ }^{89} \mathrm{Zr} \text {-labeled } \\
\text { bGNR@MSN(DOX)- } \\
\text { PEG (Zirconium } \\
\text { labeled PEGylated } \\
\text { gold nanorods, GNR, } \\
\text { coated with } \\
\text { mesoporous silica } \\
\text { nanoshell) }\end{array}$ & $\begin{array}{l}\text { PAI, PET, PTT and } \\
\text { chemotherapy }\end{array}$ & $\begin{array}{l}\text { Imaging of } 4 \mathrm{~T} 1 \\
\text { breast cancer tumors }\end{array}$ & $\begin{array}{l}\text { In vitro and in vivo } \\
\text { on mice }\end{array}$ & $\begin{array}{c}\text { NP diameter: } \\
135.9 \mathrm{~nm} ; 4.7 \text { fold } \\
\text { stronger signal from } \\
\text { PAI } 24 \mathrm{~h} \\
\text { post-injection as } \\
\text { compared to } \\
\text { pre-injection }\end{array}$ & $\begin{array}{l}\text { VEVO LAZR PA } \\
\text { imaging system }\end{array}$ & - & 2018 [155] \\
\hline & $\begin{array}{l}\text { AuNR coated with } \\
\text { CTAB. }\end{array}$ & PAI, US & $\begin{array}{l}\text { Imaging of tumor } \\
\text { metastases in mice }\end{array}$ & $\begin{array}{c}\text { In vivo } \\
\text { EGFR-targeted PAI } \\
\text { of lymph node } \\
\text { metastases and } \\
\text { tumor mass }\end{array}$ & $\begin{array}{c}\text { Enhanced PA signal } \\
\text { observed after } 24 \mathrm{~h} \\
\text { in lymph node with } \\
\text { metastases } \\
\text { post-injection of gold } \\
\text { nanorods. }\end{array}$ & $\begin{array}{l}\text { LZ-550 linear array } \\
\text { transducer, Vevo } \\
2100 \text { LAZR } \\
\text { high-frequency US } \\
\text { and PA imaging } \\
\text { system. }\end{array}$ & - & 2016 [127] \\
\hline & $\begin{array}{c}\text { Furin-cleavable } \\
\text { RVRR } \\
\text { (Arg-Val-Arg-Arg) } \\
\text { peptides (Au-RRVR } \\
\text { NPs) }\end{array}$ & PAI, PTT & $\begin{array}{l}\text { Imaging HCT } 116 \\
\text { colorectal } \\
\text { carcinomas }\end{array}$ & $\begin{array}{l}\text { In vitro and in vivo } \\
\text { imaging of tumors }\end{array}$ & $\begin{array}{l}\text { The PA signal } \\
\text { reached an intensity } \\
\text { maximum of } \\
\text { approximately } 8 \mathrm{~h} \\
\text { post-injection with a } \\
1.6 \text {-fold } \\
\text { enhancement } \\
\text { compared to the } \\
\text { initial background. }\end{array}$ & $\begin{array}{c}\text { A multispectral } \\
\text { optoacoustic } \\
\text { tomography scanner } \\
\text { with excitation light } \\
\text { of } 680-900 \mathrm{~nm}\end{array}$ & $\begin{array}{c}\text { Maynard operation } \\
\text { sequence technique } \\
(\mathrm{MOST}) \\
\text { measurement }\end{array}$ & 2021 [157] \\
\hline
\end{tabular}


Table 4. Cont.

\begin{tabular}{|c|c|c|c|c|c|c|c|c|}
\hline Classification & Material Used & Imaging Modalities & Application & Studies Conducted & $\begin{array}{l}\text { Relevant Measured } \\
\text { Parameters }\end{array}$ & Transducer Used & $\begin{array}{l}\text { Computational } \\
\text { Techniques }\end{array}$ & $\begin{array}{c}\text { Publication } \\
\text { Year/Reference }\end{array}$ \\
\hline $\begin{array}{l}\text { Gadolinium- } \\
\text { /bismuth-based }\end{array}$ & $\begin{array}{c}\text { Gd-PEG-Bi NPs } \\
\text { (hydrophobic } \\
\text { dodecanethiol-Bi } \\
\text { nanoparticles, for CT } \\
\text { and PA contrast, } \\
\text { coated in } \\
\text { gadolinium, for MRI, } \\
\text { and PEG) }\end{array}$ & $\begin{array}{c}\text { PAI, CT, MRI and for } \\
\text { PTT }\end{array}$ & $\begin{array}{l}\text { Imaging of } \mathrm{C} 6 \text { glial } \\
\text { tumors }\end{array}$ & $\begin{array}{l}\text { In vitro and in vivo } \\
\text { on mice; hemolysis } \\
\text { assay and in vivo } \\
\text { blood clearance and } \\
\text { bio-distribution }\end{array}$ & $\begin{array}{l}\text { NP diameter: } 45 \mathrm{~nm} \text {; } \\
\text { Strong PA signals at } \\
\text { low concentrations } \\
\text { of } 0.625 \mathrm{mg} / \mathrm{mL} \text { and } \\
\text { after } 30 \mathrm{~min} \text {; } \\
\text { Strongest PA signal } \\
\text { at } 3 \mathrm{~h} \text { and blood } \\
\text { half-life at } 4.69 \mathrm{~h} ; \\
\text { High biosafety and } \\
\text { NIR absorption } \\
\text { coefficient }\end{array}$ & $\begin{array}{l}\text { Endra Nexus } 128 \text { PA } \\
\text { imaging system }\end{array}$ & - & 2018 [104] \\
\hline Manganese-based & $\begin{array}{l}\mathrm{GO} / \mathrm{MnWO}_{4} / \mathrm{PEG} / \mathrm{DO} \\
\text { (Graphene-oxide, } \\
\mathrm{GO} \text {, grown in situ } \\
\text { onto manganese } \\
\text { tungsten oxide in the } \\
\text { presence of PEG and } \\
\text { loaded with } \\
\text { doxorubicin) }\end{array}$ & $\begin{array}{l}\text { PAI, MRI, PTT and } \\
\text { chemotherapy }\end{array}$ & $\begin{array}{l}\text { Imaging of breast } \\
\text { cancer tumors ( } 4 \mathrm{~T} 1 \\
\text { mouse mammary } \\
\text { carcinoma) }\end{array}$ & $\begin{array}{l}\text { In vitro and in vivo } \\
\text { on mice; PTT, } \\
\text { chemotherapy and } \\
\text { cytotoxicity }\end{array}$ & $\begin{array}{l}\text { Maximum PA signal } \\
\text { observed at tumor } \\
\text { region } 6 \mathrm{~h} \\
\text { post-injection } \\
\text { in vivo; however, the } \\
\text { signal was } \\
\text { maintained at } \\
1.4 \text { times that of } \\
\text { pre-injection at } 24 \mathrm{~h} \text {. } \\
\text { Little to no } \\
\text { cytotoxicity } \\
\text { observed }\end{array}$ & $\begin{array}{l}\text { MOST inVision128, } \\
\text { iThera Medical }\end{array}$ & - & 2018 [105] \\
\hline Iron oxide-based & $\begin{array}{l}\text { Magnetic iron oxide } \\
\text { nanoparticles }\end{array}$ & Molecular PAT & $\begin{array}{l}\text { Imaging of } 4 \mathrm{~T} 1 \\
\text { breast cancer tumors }\end{array}$ & $\begin{array}{l}\text { In vivo molecular } \\
\text { photoacoustic } \\
\text { tomography of } \\
\text { breast cancer in mice }\end{array}$ & $\begin{array}{c}\text { Post injection of } \\
\text { contrast agents PA } \\
\text { signal increased } \\
3 \text { times after } 5 \mathrm{~min} \\
\text { and } 10 \text { times after } \\
24 \mathrm{~h} .\end{array}$ & $\begin{array}{c}\text { Focused-ultrasound } \\
\text { transducer operating } \\
\text { at } 50 \mathrm{MHz} \text { and } 3.5 \\
\mathrm{MHz}\end{array}$ & $\begin{array}{l}\text { Raster scanning to } \\
\text { acquire PA images, } \\
\text { Hilbert transform } \\
\text { was used to process } \\
\text { acquired signals. }\end{array}$ & 2014 [158] \\
\hline $\begin{array}{l}\text { Copper(II) sulfide } \\
\text { nanoparticles (CuS) }\end{array}$ & $\begin{array}{l}\text { Copper(II) chloride, } \\
\text { sodium sulfide, } \\
\text { methoxy-PEG-thiol } \\
\text { to form polyethylene } \\
\text { glycol (PEG)-coated } \\
\text { copper(II) sulfide } \\
\text { nanoparticles }\end{array}$ & PAT & $\begin{array}{l}\text { Imaging of } 4 \mathrm{~T} 1 \\
\text { breast cancer tumors }\end{array}$ & $\begin{array}{l}\text { In vivo PAT of blood } \\
\text { vasculature of } 4 \mathrm{~T} 1 \\
\text { breast cancer in } \\
\text { mouse }\end{array}$ & $\begin{array}{c}\text { After } 2 \mathrm{~h} \text { and } 5 \mathrm{~min} \\
\text { of injecting contrast } \\
\text { agent, PA signal had } \\
\text { maximum intensity } \\
\text { and minute details of } \\
\text { blood vessels at } \\
\text { tumor site were } \\
\text { shown with great } \\
\text { clarity. }\end{array}$ & - & - & 2014 [159] \\
\hline
\end{tabular}


Table 5. Classification and Summary of Tumor-Targeting In Vivo Studies for PAI Dye-based Contrast Agents.

\begin{tabular}{|c|c|c|c|c|c|c|c|c|}
\hline Classification & Material Used & Imaging Modalities & Application & Studies Conducted & $\begin{array}{l}\text { Relevant Measured } \\
\text { Parameters }\end{array}$ & Transducer Used & $\begin{array}{l}\text { Computational } \\
\text { Techniques }\end{array}$ & $\begin{array}{c}\text { Publication } \\
\text { Year/Reference }\end{array}$ \\
\hline \multirow{3}{*}{ ICG-based } & ICG & PAI & $\begin{array}{l}\text { Imaging of lymph } \\
\text { vessels/nodes in } \\
\text { breast cancer tumors }\end{array}$ & $\begin{array}{l}\text { Phantom using PTFE } \\
\text { tubes; in vivo on } \\
\text { mice }\end{array}$ & $\begin{array}{l}\text { Attenuation } \\
\text { coefficient: } \\
-1.90 \mathrm{~dB} / \mathrm{mm}\end{array}$ & $\begin{array}{c}\text { Concave } \\
\text { poly(vinylidenefluoride/ } \\
\text { trifluoroethylene) } \\
\text { (P(VDF-TrFE) }) \text { US } \\
\text { transducer }\end{array}$ & $\begin{array}{l}\text { / Delay-and-sum } \\
\text { (DAS) beamforming } \\
\text { method }\end{array}$ & 2018 [154] \\
\hline & ICG-cRGD & PAI & $\begin{array}{l}\text { Imaging of human } \\
\text { glioblastoma } \\
\text { (U-87MG, high } \alpha \mathrm{v} \beta 3 \\
\text { expression) and } \\
\text { epidermoid } \\
\text { carcinoma (A431, } \\
\text { low } \alpha \mathrm{v} \beta 3 \\
\text { expression) }\end{array}$ & $\begin{array}{l}\text { In vitro and in vivo } \\
\text { on mice; followed by } \\
\text { ex vivo of mice } \\
\text { organs }\end{array}$ & $\begin{array}{l}\text { Signal: plateaued } \\
\text { after } 30-60 \text { min for } \\
\text { ICG-RGD in U-87 } \\
\text { MG and sustained } \\
\text { for } 24 \mathrm{~h} \\
\text { post-injection; } \\
25 \text { times greater for } \\
\text { U-97MG than for } \\
\text { A431 }\end{array}$ & $\begin{array}{l}\text { Vevo LAZR LZ250 } \\
\text { PA imaging system }\end{array}$ & Spectral unmixing & 2018 [17] \\
\hline & $\begin{array}{c}\text { SDF- } \\
\text { 1/ICG/PFH/DOX } \\
\text { PLGA NPs } \\
\text { (PLGA shells } \\
\text { encapsulating PFH, } \\
\text { Doxorubicin and } \\
\text { ICG and conjugated } \\
\text { to chemokine SDF-1) }\end{array}$ & $\begin{array}{l}\text { PAI, PTT and } \\
\text { chemotherapy }\end{array}$ & $\begin{array}{l}\text { Imaging of } \\
\text { metastatic lymph } \\
\text { nodes in tongue } \\
\text { squamous cell } \\
\text { carcinoma }\end{array}$ & $\begin{array}{c}\text { In vitro and in vivo } \\
\text { on rabbits }\end{array}$ & $\begin{array}{l}\text { Signal: plateaued at } \\
1 \mathrm{~h} \text { and was } \\
\text { sustained for } 24 \mathrm{~h} \\
\text { post-injection; higher } \\
\text { signal intensity for } \\
\text { targeted groups than } \\
\text { for non-targeted } \\
\text { control }\end{array}$ & $\begin{array}{l}\text { VEVO LAZR PA } \\
\text { imaging system }\end{array}$ & - & 2019 [160] \\
\hline & $\begin{array}{c}\text { Sodium hyaluronic } \\
\text { acid, } \\
\text { Ethylenediamine, } \\
\text { ICG, single-walled } \\
\text { carbon nanotubes }\end{array}$ & PAI & $\begin{array}{l}\text { In vivo Imaging of } \\
\text { SCC7 Tumor in mice }\end{array}$ & $\begin{array}{l}\text { In vivo and ex vivo } \\
\text { on mice }\end{array}$ & $\begin{array}{l}\text { PA signal was not } \\
\text { clear with the } \\
\text { injection of free ICG. } \\
\text { ICG combined with } \\
\text { hyaluronic acid } \\
\text { nanoparticles in } \\
\text { SWCNT } \\
\text { encapsulation } \\
\text { provided strong } \\
\text { signals. Image } \\
\text { contrast decreased } \\
\text { after } 48 \text { h of injecting } \\
\text { IHANPT. }\end{array}$ & $\begin{array}{l}\text { Endra Nexus128 } \\
\text { imaging system }\end{array}$ & - & 2016 [89] \\
\hline
\end{tabular}


Table 5. Cont.

\begin{tabular}{|c|c|c|c|c|c|c|c|c|}
\hline Classification & Material Used & Imaging Modalities & Application & Studies Conducted & $\begin{array}{l}\text { Relevant Measured } \\
\text { Parameters }\end{array}$ & Transducer Used & $\begin{array}{c}\text { Computational } \\
\text { Techniques }\end{array}$ & $\begin{array}{c}\text { Publication } \\
\text { Year/Reference }\end{array}$ \\
\hline & $\begin{array}{l}\text { ICG, polyethylene } \\
\text { glycol, reduced } \\
\text { Nano-graphene } \\
\text { oxide composite }\end{array}$ & $\begin{array}{l}\text { PAI, Fluorescence } \\
\text { imaging }\end{array}$ & $\begin{array}{l}\text { In vivo imaging of } \\
\text { Hela tumor (cervical } \\
\text { carcinoma) models } \\
\text { in mice }\end{array}$ & $\begin{array}{l}\text { PAI of Phantoms, In } \\
\text { Vivo PAI, In Vivo } \\
\text { Toxicity Assessment }\end{array}$ & $\begin{array}{l}\text { Nanocomposite } \\
\text { produced minimal } \\
\text { toxicity. Blood } \\
\text { circulation time was } \\
6 \mathrm{~h} \text {. PAI showed } \\
\text { accumulation and } \\
\text { distribution of } \\
\text { injected contrast } \\
\text { agents at the tumor } \\
\text { site. }\end{array}$ & $\begin{array}{l}\text { Olympus focused } \\
\text { ultrasound } \\
\text { transducer with a } \\
\text { central frequency of } \\
10 \text { MHz. } \\
\text { Acoustic-resolution } \\
\text { photoacoustic } \\
\text { microscopy system }\end{array}$ & - & 2016 [149] \\
\hline $\begin{array}{l}\text { Squaraine dye } \\
\text { nanoprobe }\end{array}$ & $\begin{array}{l}\text { squaraine dye SQ1 } \\
\text { constructed from } \\
\text { ethyl-grafted } \\
\text { 1,8-naphtholactam } \\
\text { and square acid in a } \\
\text { donor-acceptor- } \\
\text { donor } \\
\text { structure }\end{array}$ & $\begin{array}{l}\text { PAI, fluorescence } \\
\text { imaging and PTT }\end{array}$ & $\begin{array}{l}\text { PAI of breast cancer } \\
\text { cells (MDA-MB-231 } \\
\text { and MCF-7) }\end{array}$ & $\begin{array}{l}\text { In vitro and in vivo } \\
\text { imaging }\end{array}$ & $\begin{array}{l}\text { SQ1nanoprobe } \\
\text { performed well in } \\
\text { both PA imaging and } \\
\text { PTT of solid tumors. }\end{array}$ & $\begin{array}{l}\text { PA images and } \\
\text { corresponding PA } \\
\text { intensities at } 930 \mathrm{~nm} \\
\text { were obtained by a } \\
\text { PA microscopy } \\
\text { system }\end{array}$ & - & 2020 [161] \\
\hline
\end{tabular}




\subsection{Biosensors and Nanoprobes for In Vivo Tumor Studies}

Since sensitivity and selectivity are vital for the early detection of cancer metastases, researchers have developed probes that react with molecules that have major functional roles in pathology - mainly in tumor growth. Such materials have been developed for other imaging modalities such as fluorescence imaging [162], PET, MRI, computed tomography (CT), and echography [163] and tested in vivo on tumor-bearing mice. PAI nanoprobes can detect cancer-associated growth on a molecular level and help clinicians administer precise dosage amounts to cancer patients, thus decreasing the adverse side effects of conventional chemotherapy. One such probe was developed by Wang et al. [78], where elevated nitric oxide levels, a characteristic of tumor sites, would lead to a linear increase in PA signal based on concentration levels. This probe was composed of benzothiadiazole conjugated to diphenylamine on both ends in a donor-acceptor-donor conformation. Chen et al. [146] used a novel approach to synthesize a $\mathrm{pH}$-sensitive probe that performed the dual action of changing the PA signal intensity based on $\mathrm{pH}$ in the microenvironment, with increased signal in acidic environments, as well as performing photothermal action by self-assembly of human serum albumin and croconine-dye nanoparticles to eliminate tumor cells. The same research group used this probe to detect changes in tumor acidity by developing a metal, calcium ion and organic ligand, dicarboxylic cisplatin prodrug, nanoparticles covered with poly-l-histidine-PEG (pHis-PEG) to oxidize $\mathrm{H}_{2} \mathrm{O}_{2}$ and thus, perform dualcancer therapy and real-time in vivo imaging [164].

There are a limited number of studies in the biosensor field, including PAI. This could be attributed to the tedious process of validating biosensors to determine whether they are clinically applicable and safe for use [165]. Since the interaction between the probe molecule and the target molecule should be highly selective, i.e., it should not respond adversely to other components in vivo, specifically, if other benign diseases exhibit increased concentrations of the target molecule. The reproducibility and commercialization of these biosensors might contribute to this comparatively unexplored field of probe and biosensor in cancer research. Figure 6 presents a summary of the studies conducted using different types of PAI contrast agents over the past four years.

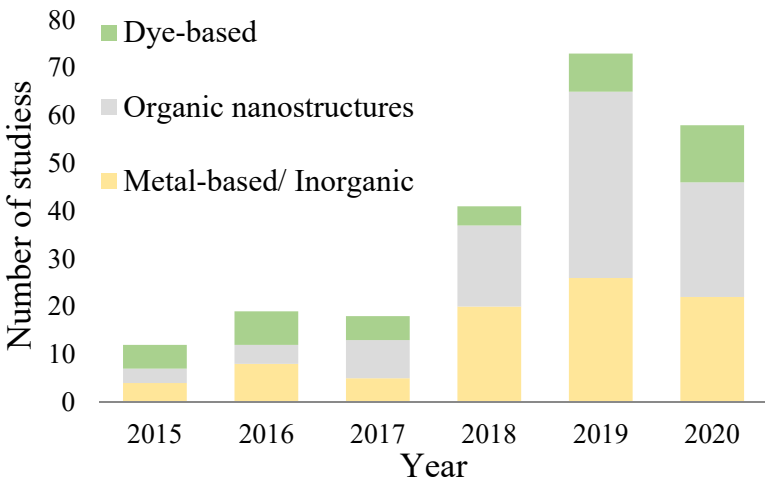

(a)

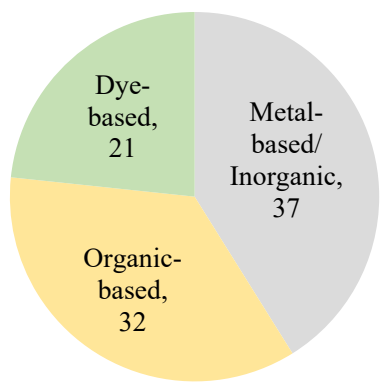

(b)

Figure 6. (a) No. of studies in the last four years. (b) Total number of studies in the last four years based on classification.

\section{Conclusions, Challenges and Future Directions}

PAI is a promising modality for real-time imaging which can be developed by combining the properties of exogenous contrast agents such as metallic, carbon-based, semimetallic, polymer-based nanomaterials and dyes. This review follows and categorizes the development of exogenous contrast agents for in vivo imaging, specifically tumor imaging. Different strategies have been exploited to enhance the PA signal, including incorporating moieties, inducing the plasmon coupling effect, coupling different classes of nanomaterials and dyes, forming stimuli-responsive nanoagents, magnetic and photo-induced electron 
transfer for background signal reduction, and self-assembly of materials. Other techniques include improving imaging systems for the synchronized detection of PA signals [166].

The field of optoacoustics/PA has vast implications for clinical translation, with one of the first studies for intraoperative breast cancer surgeries revealing successful tumor margin identification and identification of the biochemical contents. The current stateof-the-art in tumor margin definition is histological analysis, which requires the removal of the tumor and a 24-h period for analysis. The development of PAI implies that the clinical need for fast and real-time processing can finally be met in oncology. With regards to image characteristics, this study showed that PAI used a scan time of $20 \mathrm{~min}$ along with satisfactory penetration depths and high-resolution images compared to fluorescence, Raman spectroscopy, and diffuse reflection imaging [167]. Numerous studies revealed promising results [168]; however, extensive cohort studies are still needed before PAI can be used as a state-of-the-art imaging modality in oncology with a future trend towards NIR-II contrast agent development. Future studies may focus on developing more efficient stimuli-responsive agents that track shifts in absorptions peaks based on changes in the tumor microenvironment, while evaluating its toxicity, biocompatibility, biodegradability, and photostability.

Author Contributions: Conceptualization, S.D. and G.H.; methodology, A.F., S.S., S.D, N.A. and G.H.; validation, S.D., N.A. and G.H.; formal analysis, A.F., S.S. and N.A.; investigation, A.F., S.S. and N.A.; resources, S.D.; writing—original draft preparation, A.F. and S.S.; writing—review and editing, S.D., N.A. and G.H.; visualization, A.F., S.S. and N.A.; supervision, S.D. and G.H.; project administration, S.D. and G.H.; funding acquisition, S.D. All authors have read and agreed to the published version of the manuscript.

Funding: The work in this paper was supported, in part, by the Open Access Program from the American University of Sharjah [Award \#: OAPCEN-1410-E00025]. This paper represents the opinions of the author(s) and does not mean to represent the position or opinions of the American University of Sharjah.

Acknowledgments: Afifa Farooq, Shafiya Sabah, and Nour Alsawaftah thank the Biomedical Engineering Graduate Program at the American University of Sharjah for funding their graduate studies.

Conflicts of Interest: The authors declare no conflict of interest.

\section{References}

1. Deán-Ben, X.L.; Gottschalk, S.; McLarney, B.; Shoham, S.; Razansky, D. Advanced optoacoustic methods for multiscale imaging of in vivo dynamics. Chem. Soc. Rev. 2017, 46, 2158-2198. [CrossRef] [PubMed]

2. Liu, Y.; Nie, L.; Chen, X. Photoacoustic molecular imaging: From multiscale biomedical applications towards early-stage theranostics. Trends Biotechnol. 2016, 34, 420-433. [CrossRef] [PubMed]

3. Yao, J.; Wang, L.V. Photoacoustic tomography: Fundamentals, advances and prospects. Contrast Media Mol. Imaging 2011, 6, 332-345. [CrossRef]

4. Sun, Y.; Jiang, H.; O’Neill, B.E. Photoacoustic imaging: An emerging optical modality in diagnostic and theranostic medicine. J. Biosens. Bioelectron. 2011, 2, 3. [CrossRef]

5. Bell, A.G. On the production and reproduction of sound by light. Am. J. Sci. 1880, 29, 305-324. [CrossRef]

6. Esenaliev, R.O.; Karabutov, A.A.; Tittel, F.K.; Fornage, B.D.; Thomsen, S.L.; Stelling, C.; Oraevsky, A.A. Laser optoacoustic imaging for breast cancer diagnostics: Limit of detection and comparison with x-ray and ultrasound imaging. In Optical Tomography and Spectroscopy of Tissue: Theory, Instrumentation, Model, and Human Studies II; International Society for Optics and Photonics: Bellingham, WA, USA, 1997; Volume 2979, pp. 71-83.

7. Oraevsky, A.A.; Andreev, V.A.; Karabutov, A.A.; Fleming, R.D.; Gatalica, Z.; Singh, H.; Esenaliev, R.O. Laser optoacoustic imaging of the breast: Detection of cancer angiogenesis. In Optical Tomography and Spectroscopy of Tissue III; International Society for Optics and Photonics: Bellingham, WA, USA, 1999; Volume 3597, pp. 352-363.

8. Oraevsky, A.A.; Jacques, S.L.; Esenaliev, R.O.; Tittel, F.K. Direct measurement of laser fluence distribution and optoacoustic imaging in heterogeneous tissues. In Laser Interaction with Hard and Soft Tissue II; International Society for Optics and Photonics: Bellingham, WA, USA, 1995; Volume 2323, pp. 37-46.

9. Bertolotti, M.; Voti, R.L. A note on the history of photoacoustic, thermal lensing, and photothermal deflection techniques. J. Appl. Phys. 2020, 128, 230901. [CrossRef] 
10. Oraevsky, A.A.; Karabutov, A.A.; Solomatin, S.V.; Savateeva, E.V.; Andreev, V.A.; Gatalica, Z.; Singh, H.; Fleming, R.D. Laser optoacoustic imaging of breast cancer in vivo. In Biomedical Optoacoustics II; International Society for Optics and Photonics: Bellingham, WA, USA, 2001; Volume 4256, pp. 6-15.

11. De Mul, F.F.M.; Pilatou, M.C.; Kolkman, R.G.M.; Hondebrink, E.; Steenbergen, W. Photoacoustic imaging of blood vessels in tissues. In Laser Florence 2001: A Window on the Laser Medicine World; International Society for Optics and Photonics: Bellingham, WA, USA, 2002; Volume 4903, pp. 208-213.

12. Xavierselvan, M.; Singh, M.K.A.; Mallidi, S. In vivo tumor vascular imaging with light emitting diode-based photoacoustic imaging system. Sensors 2020, 20, 4503. [CrossRef]

13. Hirasawa, T.; Iwatate, R.J.; Kamiya, M.; Okawa, S.; Urano, Y.; Ishihara, M. Multispectral photoacoustic imaging of tumours in mice injected with an enzyme-activatable photoacoustic probe. J. Opt. 2017, 19, 14002. [CrossRef]

14. Ma, Z.M.; Qin, H.P.; Chen, H.M.; Yang, H.; Xu, J.; Yang, S.P.; Hu, J.P.; Xing, D.P. Phage display-derived oligopeptide-functionalized probes for in vivo specific photoacoustic imaging of osteosarcoma. Nanomed. Nanotechnol. Biol. Med. 2017, 13, 111-121. [CrossRef]

15. Li, X.; Wang, D.; Ran, H.; Hao, L.; Cao, Y.; Ao, M.; Zhang, N.; Song, J.; Zhang, L.; Yi, H.; et al. A preliminary study of photoacoustic/ultrasound dual-mode imaging in melanoma using MAGE-targeted gold nanoparticles. Biochem. Biophys. Res. Commun. 2018, 502, 255-261. [CrossRef]

16. Kim, J.-W.; Galanzha, E.I.; Shashkov, E.V.; Moon, H.-M.; Zharov, V.P. Golden carbon nanotubes as multimodal photoacoustic and photothermal high-contrast molecular agents. Nat. Nanotechnol. 2009, 4, 688-694. [CrossRef]

17. Capozza, M.; Blasi, F.; Valbusa, G.; Oliva, P.; Cabella, C.; Buonsanti, F.; Cordaro, A.; Pizzuto, L.; Maiocchi, A.; Poggi, L. Photoacoustic imaging of integrin-overexpressing tumors using a novel ICG-based contrast agent in mice. Photoacoustics 2018, 11, 36-45. [CrossRef] [PubMed]

18. de la Zerda, A.; Bodapati, S.; Teed, R.; May, S.Y.; Tabakman, S.M.; Liu, Z.; Khuri-Yakub, B.T.; Chen, X.; Dai, H.; Gambhir, S.S. Family of enhanced photoacoustic imaging agents for high-sensitivity and multiplexing studies in living mice. ACS Nano 2012, 6, 4694-4701. [CrossRef] [PubMed]

19. Zanganeh, S.; Li, H.; Kumavor, P.D.; Alqasemi, U.S.; Aguirre, A.; Mohammad, I.; Stanford, C.; Smith, M.B.; Zhu, Q. Photoacoustic imaging enhanced by indocyanine green-conjugated single-wall carbon nanotubes. J. Biomed. Opt. 2013, 18, 096006. [CrossRef] [PubMed]

20. Lavaud, J.; Henry, M.; Coll, J.-L.; Josserand, V. Exploration of melanoma metastases in mice brains using endogenous contrast photoacoustic imaging. Int. J. Pharm. 2017, 532, 704-709. [CrossRef]

21. Neuwirth, M.; Sinnamon, A.J.; Schultz, S.; Seghal, C.; Xu, G.; Karakousis, G.C. Detection of melanoma metastases in regional lymph nodes using multispectral photoacoustic imaging. J. Am. Coll. Surg. 2017, 225, S189. [CrossRef]

22. Cheng, K.; Cheng, Z. Diagnostic applications. In Adverse Effects of Engineered Nanomaterials; Fadeel, B., Pietroiusti, A., Shvedova, A.A., Eds.; Elsevier: Amsterdam, The Netherlands, 2012; pp. 265-284.

23. Johnstonbaugh, K.; Agrawal, S.; Durairaj, D.A.; Homewood, M.; Karri, S.P.K.; Kothapalli, S.-R. Novel deep learning architecture for optical fluence dependent photoacoustic target localization. In Photons Plus Ultrasound: Imaging and Sensing 2019; International Society for Optics and Photonics: Bellingham, WA, USA, 2019; Volume 10878, p. 108781L.

24. Costa, M.M.; Shah, A.; Rivens, I.; Box, C.; O'Shea, T.; Papaevangelou, E.; Bamber, J.; ter Haar, G. Quantitative photoacoustic imaging study of tumours in vivo: Baseline variations in quantitative measurements. Photoacoustics 2018, 13, 53-65. [CrossRef] [PubMed]

25. Steinberg, I.; Huland, D.M.; Vermesh, O.; Frostig, H.E.; Tummers, W.S.; Gambhir, S.S. Photoacoustic clinical imaging. Photoacoustics 2019, 14, 77-98. [CrossRef]

26. Mehrmohammadi, M.; Yoon, S.J.; Yeager, D.; Emelianov, S. Photoacoustic imaging for cancer detection and staging. Curr. Mol. Imaging 2013, 2, 89-105. [CrossRef]

27. Wilson, K.E.; Wang, T.Y.; Willmann, J.K. Acoustic and photoacoustic molecular imaging of cancer. J. Nucl. Med. 2013, 54, 1851-1854. [CrossRef]

28. Attia, A.B.E.; Balasundaram, G.; Moothanchery, M.; Dinish, U.; Bi, R.; Ntziachristos, V.; Olivo, M. A review of clinical photoacoustic imaging: Current and future trends. Photoacoustics 2019, 16, 100144. [CrossRef] [PubMed]

29. Zhao, T.; Desjardins, A.E.; Ourselin, S.; Vercauteren, T.; Xia, W. Minimally invasive photoacoustic imaging: Current status and future perspectives. Photoacoustics 2019, 16, 100146. [CrossRef] [PubMed]

30. Vu, T.; Razansky, D.; Yao, J. Listening to tissues with new light: Recent technological advances in photoacoustic imaging. J. Opt. 2019, 21, 103001. [CrossRef] [PubMed]

31. Gargiulo, S.; Albanese, S.; Mancini, M. State-of-the-art preclinical photoacoustic imaging in oncology: Recent advances in cancer theranostics. Contrast Media Mol. Imaging 2019, 2019, 5080267. [CrossRef] [PubMed]

32. Upputuri, P.K.; Pramanik, M. Recent advances in photoacoustic contrast agents for in vivo imaging. WIREs Nanomed. Nanobiotechnol. 2020, 12, e1618. [CrossRef]

33. Zhang, J.; Ning, L.; Zeng, Z.; Pu, K. Development of second near-infrared photoacoustic imaging agents. Trends Chem. 2021, 3 , 305-317. [CrossRef]

34. Liu, W.-W.; Li, P.-C. Photoacoustic imaging of cells in a three-dimensional microenvironment. J. Biomed. Sci. 2020, 27, 3. [CrossRef]

35. Siddique, S.; Chow, J.C.L. Application of nanomaterials in biomedical imaging and cancer therapy. Nanomaterials 2020, 10, 1700. [CrossRef] 
36. Lusic, H.; Grinstaff, M. X-ray-computed tomography contrast agents. Chem. Rev. 2012, 113, 1641-1666. [CrossRef]

37. Ignee, A.; Atkinson, N.S.; Schuessler, G.; Dietrich, C. Ultrasound contrast agents. Endosc. Ultrasound 2016, 5, 355-362. [CrossRef]

38. Kiani, A.; Esquevin, A.; Lepareur, N.; Bourguet, P.; Le Jeune, F.; Gauvrit, J. Main applications of hybrid PET-MRI contrast agents: A review. Contrast Media Mol. Imaging 2015, 11, 92-98. [CrossRef] [PubMed]

39. Criscione, J.M.; Dobrucki, L.W.; Zhuang, Z.W.; Papademetris, X.; Simons, M.; Sinusas, A.J.; Fahmy, T.M. Development and application of a multimodal contrast agent for SPECT/CT hybrid imaging. Bioconjug. Chem. 2011, 22, 1784-1792. [CrossRef] [PubMed]

40. Xia, J.; Yao, J.; Wang, L. Photoacoustic tomography: Principles and advances. Prog. Electromagn. Res. 2014, 147, 1-22. [CrossRef] [PubMed]

41. Zhang, Y.; Hong, H.; Cai, W. Photoacoustic imaging. Cold Spring Harb. Protoc. 2011, 2011, 1015-1025. [CrossRef] [PubMed]

42. Weissleder, R. A clearer vision for in vivo imaging. Nat. Biotechnol. 2001, 19, 316-317. [CrossRef] [PubMed]

43. Lyu, Y.; Li, J.; Pu, K. Second near-infrared absorbing agents for photoacoustic imaging and photothermal therapy. Small Methods 2019, 3, 1900553. [CrossRef]

44. Upputuri, P.K.; Pramanik, M. Photoacoustic imaging in the second near-infrared window: A review. J. Biomed. Opt. 2019, 24, 040901. [CrossRef]

45. Hoshyar, N.; Gray, S.; Han, H.; Bao, G. The effect of nanoparticle size on in vivo pharmacokinetics and cellular interaction. Nanomedicine 2016, 11, 673-692. [CrossRef]

46. Sharma, A.; Jain, N.; Sareen, R. Nanocarriers for diagnosis and targeting of breast cancer. BioMed. Res. Int. 2013, 2013, 960821. [CrossRef]

47. Holowka, E.P.; Bhatia, S.K. Drug Delivery: Materials Design and Clinical Perspective; Springer: New York, NY, USA, 2014; ISBN 9781493919987.

48. Yoo, J.-W.; Doshi, N.; Mitragotri, S. Adaptive micro and nanoparticles: Temporal control over carrier properties to facilitate drug delivery. Adv. Drug Deliv. Rev. 2011, 63, 1247-1256. [CrossRef]

49. Li, K.; Liu, B. Polymer-encapsulated organic nanoparticles for fluorescence and photoacoustic imaging. Chem. Soc. Rev. 2014, 43, 6570-6597. [CrossRef] [PubMed]

50. Xiao, W.; Li, Y.; Hu, C.; Huang, Y.; He, Q.; Gao, H. Melanin-originated carbonaceous dots for triple negative breast cancer diagnosis by fluorescence and photoacoustic dual-mode imaging. J. Colloid Interface Sci. 2017, 497, 226-232. [CrossRef] [PubMed]

51. Jia, Q.; Zheng, X.; Ge, J.; Liu, W.; Ren, H.; Chen, S.; Wen, Y.; Zhang, H.; Wu, J.; Wang, P. Synthesis of carbon dots from Hypocrella bambusae for bimodel fluorescence/photoacoustic imaging-guided synergistic photodynamic/photothermal therapy of cancer. $J$. Colloid Interface Sci. 2018, 526, 302-311. [CrossRef] [PubMed]

52. Parvin, N.; Mandal, T.K. Dually emissive P,N-co-doped carbon dots for fluorescent and photoacoustic tissue imaging in living mice. Microchim. Acta 2017, 184, 1117-1125. [CrossRef]

53. Ge, J.; Jia, Q.; Liu, W.; Guo, L.; Liu, Q.; Lan, M.; Zhang, H.; Meng, X.; Wang, P. Red-emissive carbon dots for fluorescent, photoacoustic, and thermal theranostics in living mice. Adv. Mater. 2015, 27, 4169-4177. [CrossRef] [PubMed]

54. Chen, Q.; Liang, C.; Sun, X.; Chen, J.; Yang, Z.; Zhao, H.; Feng, L.; Liu, Z. $\mathrm{H}_{2} \mathrm{O}_{2}$-responsive liposomal nanoprobe for photoacoustic inflammation imaging and tumor theranostics via in vivo chromogenic assay. Proc. Natl. Acad. Sci. USA 2017, 114, 5343-5348. [CrossRef]

55. Zhang, R.; Feng, L.; Dong, Z.; Wang, L.; Liang, C.; Chen, J.; Ma, Q.; Chen, Q.; Wang, Y.; Liu, Z. Glucose and oxygen exhausting liposomes for combined cancer starvation and hypoxia-activated therapy. Biomaterials 2018, 162, 123-131. [CrossRef]

56. Liu, K.; Wang, X.; Ntziachristos, V.; Marsch, S.; Hunziker, P. Polymeric nanosystems for near-infrared multispectral photoacoustic imaging: Synthesis, characterization and in vivo evaluation. Eur. Polym. J. 2017, 88, 713-723. [CrossRef]

57. AlSawaftah, N.; Pitt, W.G.; Husseini, G.A. Dual-targeting and stimuli-triggered liposomal drug delivery in cancer treatment. ACS Pharmacol. Transl. Sci. 2021, 4, 1028-1049. [CrossRef]

58. Neumann, P.R.; Erdmann, F.; Holthof, J.; Hädrich, G.; Green, M.; Rao, J.; Dailey, L.A. Different PEG-PLGA matrices influence in vivo optical/photoacoustic imaging performance and biodistribution of NIR-emitting $\pi$-conjugated polymer contrast agents Adv. Health Mater. 2020, 10, 2001089. [CrossRef]

59. Abelha, T.F.; Dreiss, C.A.; Green, M.A.; Dailey, L.A. Conjugated polymers as nanoparticle probes for fluorescence and photoacoustic imaging. J. Mater. Chem. B 2020, 8, 592-606. [CrossRef] [PubMed]

60. Kim, H.; Lee, H.; Moon, H.; Kang, J.; Jang, Y.; Kim, D.; Kim, J.; Huynh, E.; Zheng, G.; Kim, H.; et al. Resonance-based frequency-selective amplification for increased photoacoustic imaging sensitivity. ACS Photon. 2019, 6, 2268-2276. [CrossRef]

61. Li, C.; Liu, C.; Fan, Y.; Ma, X.; Zhan, Y.; Lu, X.; Sun, Y. Recent development of near-infrared photoacoustic probes based on small-molecule organic dye. RSC Chem. Biol. 2021, 2, 743-758. [CrossRef] [PubMed]

62. Paproski, R.J.; Forbrich, A.; Huynh, E.; Chen, J.; Lewis, J.D.; Zheng, G.; Zemp, R.J. Porphyrin nanodroplets: Sub-micrometer ultrasound and photoacoustic contrast imaging agents. Small 2016, 12, 371-380. [CrossRef] [PubMed]

63. Gao, D.; Zhang, B.; Liu, Y.; Hu, D.; Sheng, Z.; Zhang, X.; Yuan, Z. Molecular engineering of near-infrared light-responsive BODIPY-based nanoparticles with enhanced photothermal and photoacoustic efficiencies for cancer theranostics. Theranostics 2019, 9, 5315-5331. [CrossRef] 
64. Wang, Z.; Upputuri, P.K.; Zhen, X.; Zhang, R.; Jiang, Y.; Ai, X.; Zhang, Z.; Hu, M.; Meng, Z.; Lu, Y.; et al. pH-sensitive and biodegradable charge-transfer nanocomplex for second near-infrared photoacoustic tumor imaging. Nano Res. 2019, 12, 49-55. [CrossRef]

65. Miao, Q.; Lyu, Y.; Ding, D.; Pu, K. Semiconducting oligomer nanoparticles as an activatable photoacoustic probe with amplified brightness for in vivo imaging of $\mathrm{pH}$. Adv. Mater. 2016, 28, 3662-3668. [CrossRef]

66. Dragulescu-Andrasi, A.; Kothapalli, S.-R.; Tikhomirov, G.; Rao, J.; Gambhir, S.S. Activatable oligomerizable imaging agents for photoacoustic imaging of furin-like activity in living subjects. J. Am. Chem. Soc. 2013, 135, 11015-11022. [CrossRef]

67. Jung, D.; Park, S.; Lee, C.; Kim, H. Recent progress on near-infrared photoacoustic imaging: Imaging modality and organic semiconducting agents. Polymers 2019, 11, 1693. [CrossRef]

68. Bharathiraja, S.; Manivasagan, P.; Moorthy, M.S.; Bui, N.Q.; Jang, B.; Phan, T.T.V.; Jung, W.-K.; Kim, Y.-M.; Lee, K.D.; Oh, J. Photo-based PDT/PTT dual model killing and imaging of cancer cells using phycocyanin-polypyrrole nanoparticles. Eur. J. Pharm. Biopharm. 2017, 123, 20-30. [CrossRef]

69. Guo, Y.; Wang, X.-Y.; Chen, Y.-L.; Liu, F.-Q.; Tan, M.-X.; Ao, M.; Yu, J.-H.; Ran, H.-T.; Wang, Z.-X.; Guo, Y.; et al. A light-controllable specific drug delivery nanoplatform for targeted bimodal imaging-guided photothermal/chemo synergistic cancer therapy. Acta Biomater. 2018, 80, 308-326. [CrossRef] [PubMed]

70. Mattu, C.; Brachi, G.; Menichetti, L.; Flori, A.; Armanetti, P.; Ranzato, E.; Martinotti, S.; Nizzero, S.; Ferrari, M.; Ciardelli, G Alternating Block Copolymer-Based Nanoparticles as Tools to Modulate the Loading of Multiple Chemotherapeutics and Imaging Probes. Acta Biomater. 2018, 80, 341-351. [CrossRef] [PubMed]

71. Xiao, W.; Wang, P.; Ou, C.; Huang, X.; Tang, Y.; Wu, M.; Si, W.; Shao, J.; Huang, W.; Dong, X. 2-Pyridone-Functionalized Aza-BODIPY Photosensitizer for Imaging-Guided Sustainable Phototherapy. Biomaterials 2018, 183, 1-9. [CrossRef] [PubMed]

72. Sheng, D.; Liu, T.; Deng, L.; Zhang, L.; Li, X.; Xu, J.; Hao, L.; Li, P.; Ran, H.; Chen, H.; et al. Perfluorooctyl Bromide \& Indocyanine Green Co-Loaded Nanoliposomes for Enhanced Multimodal Imaging-Guided Phototherapy. Biomaterials 2018, 165, 1-13. [CrossRef]

73. Wang, F.; Huang, Q.; Wang, Y.; Shi, L.; Shen, Y.; Guo, S. NIR-Light and GSH Activated Cytosolic P65-ShRNA Delivery for Precise Treatment of Metastatic Cancer. J. Control. Release 2018, 288, 126-135. [CrossRef]

74. Deng, L.; Xu, Y.; Sun, C.; Yun, B.; Sun, Q.; Zhao, C.; Li, Z. Functionalization of Small Black Phosphorus Nanoparticles for Targeted Imaging and Photothermal Therapy of Cancer. Sci. Bull. 2018, 63, 917-924. [CrossRef]

75. Weng, Y.; Guan, S.; Lu, H.; Meng, X.; Kaassis, A.Y.; Ren, X.; Qu, X.; Sun, C.; Xie, Z.; Zhou, S. Confinement of Carbon Dots Localizing to the Ultrathin Layered Double Hydroxides toward Simultaneous Triple-Mode Bioimaging and Photothermal Therapy. Talanta 2018, 184, 50-57. [CrossRef] [PubMed]

76. Cheng, Y.; Tan, X.; Wang, J.; Wang, Y.; Song, Y.; You, Q.; Sun, Q.; Liu, L.; Wang, S.; Tan, F.; et al. Polymer-Based Gadolinium Oxide Nanocomposites for FL/MR/PA Imaging Guided and Photothermal/Photodynamic Combined Anti-Tumor Therapy. J. Control. Release 2018, 277, 77-88. [CrossRef]

77. Wang, F.; Huang, Q.; Wang, Y.; Zhang, W.; Lin, R.; Yu, Y.; Shen, Y.; Cui, H.; Guo, S. Rational Design of Multimodal Therapeutic Nanosystems for Effective Inhibition of Tumor Growth and Metastasis. Acta Biomater. 2018, 77, 240-254. [CrossRef]

78. Wang, S.; Li, Z.; Liu, Y.; Feng, G.; Zheng, J.; Yuan, Z.; Zhang, X. Activatable Photoacoustic and Fluorescent Probe of Nitric Oxide for Cellular and in Vivo Imaging. Sens. Actuators B Chem. 2018, 267, 403-411. [CrossRef]

79. Lin, G.; Zhang, Y.; Zhu, C.; Chu, C.; Shi, Y.; Pang, X.; Ren, E.; Wu, Y.; Mi, P.; Xia, H.; et al. Photo-excitable hybrid nanocomposites for image-guided photo/TRAIL synergistic cancer therapy. Biomaterials 2018, 176, 60-70. [CrossRef] [PubMed]

80. Su, Y.Y.; Yao, H.; Zhao, S.; Tian, W.; Liu, W.F.; Wang, S.; Liu, Y.; Tian, Y.; Zhang, X.D.; Teng, Z.G.; et al. Ag-HPBs by a coatingetching strategy and their derived injectable implants for enhanced tumor photothermal treatment. J. Colloid Interface Sci. 2018, 512, 439-445. [CrossRef] [PubMed]

81. Chen, H.; Zhang, J.; Chang, K.; Men, X.; Fang, X.; Zhou, L.; Li, D.; Gao, D.; Yin, S.; Zhang, X.; et al. Highly absorbing multispectral near-infrared polymer nanoparticles from one conjugated backbone for photoacoustic imaging and photothermal therapy. Biomaterials 2017, 144, 42-52. [CrossRef] [PubMed]

82. Jiang, Y.; Cui, D.; Fang, Y.; Zhen, X.; Upputuri, P.K.; Pramanik, M.; Ding, D.; Pu, K. Amphiphilic semiconducting polymer as multifunctional nanocarrier for fluorescence/photoacoustic imaging guided chemo-photothermal therapy. Biomaterials 2017, 145, 168-177. [CrossRef] [PubMed]

83. Li, Y.; Jiang, C.; Zhang, D.; Wang, Y.; Ren, X.; Ai, K.; Chen, X.; Lu, L. Targeted polydopamine nanoparticles enable photoacoustic imaging guided chemo-photothermal synergistic therapy of tumor. Acta Biomater. 2016, 47, 124-134. [CrossRef] [PubMed]

84. Jin, Y.; Ma, X.; Zhang, S.; Meng, H.; Xu, M.; Yang, X.; Xu, W.; Tian, J. A tantalum oxide-based core/shell nanoparticle for triplemodality image-guided chemo-thermal synergetic therapy of esophageal carcinoma. Cancer Lett. 2017, 397, 61-71. [CrossRef]

85. Liang, X.; Fang, L.; Li, X.; Zhang, X.; Wang, F. Activatable near infrared dye conjugated hyaluronic acid-based nanoparticles as a targeted theranostic agent for enhanced fluorescence/CT/photoacoustic imaging guided photothermal therapy. Biomaterials 2017, 132, 72-84. [CrossRef]

86. Hu, D.; Sheng, Z.; Gao, G.; Siu, F.; Liu, C.; Wan, Q.; Gong, P.; Zheng, H.; Ma, Y.; Cai, L. Activatable albumin-photosensitizer nanoassemblies for triple-modal imaging and thermal-modulated photodynamic therapy of cancer. Biomaterials 2016, 93, 10-19. [CrossRef] 
87. Li, W.; Zheng, C.; Pan, Z.; Chen, C.; Hu, D.; Gao, G.; Kang, S.; Cui, H.; Gong, P.; Cai, L. Smart hyaluronidase-actived theranostic micelles for dual-modal imaging guided photodynamic therapy. Biomaterials 2016, 101, 10-19. [CrossRef]

88. Xie, L.; Wang, G.; Zhou, H.; Zhang, F.; Guo, Z.; Liu, C.; Zhang, X.; Zhu, L. Functional long circulating single walled carbon nanotubes for fluorescent/photoacoustic imaging-guided enhanced phototherapy. Biomaterials 2016, 103, 219-228. [CrossRef]

89. Attia, A.B.E.; Ho, C.J.H.; Chandrasekharan, P.; Balasundaram, G.; Tay, H.C.; Burton, N.C.; Chuang, K.-H.; Ntziachristos, V.; Olivo, M. Multispectral optoacoustic and MRI coregistration for molecular imaging of orthotopic model of human glioblastoma. J. Biophoton. 2016, 9, 701-708. [CrossRef] [PubMed]

90. Moon, H.; Kang, J.; Sim, C.; Kim, J.; Lee, H.; Chang, J.H.; Kim, H. Multifunctional theranostic contrast agent for photoacousticsand ultrasound-based tumor diagnosis and ultrasound-stimulated local tumor therapy. J. Control. Release 2015, $218,63-71$. [CrossRef] [PubMed]

91. Sim, C.; Kim, H.; Moon, H.; Lee, H.; Chang, J.H.; Kim, H. Photoacoustic-based nanomedicine for cancer diagnosis and therapy. J. Control. Release 2015, 203, 118-125. [CrossRef] [PubMed]

92. Xie, C.; Upputuri, P.K.; Zhen, X.; Pramanik, M.; Pu, K. Self-Quenched Semiconducting Polymer Nanoparticles for Amplified in Vivo Photoacoustic Imaging. Biomaterials 2017, 119, 1-8. [CrossRef]

93. Zheng, X.; Ge, J.; Wu, J.; Liu, W.; Guo, L.; Jia, Q.; Ding, Y.; Zhang, H.; Wang, P. Biodegradable Hypocrellin Derivative Nanovesicle as a Near-Infrared Light-Driven Theranostic for Dually Photoactive Cancer Imaging and Therapy. Biomaterials 2018, 185, 133-141. [CrossRef]

94. Lee, C.; Kwon, W.; Beack, S.; Lee, D.; Park, Y.; Kim, H.; Hahn, S.K.; Rhee, S.-W.; Kim, C. Biodegradable Nitrogen-Doped Carbon Nanodots for Non-Invasive Photoacoustic Imaging and Photothermal Therapy. Theranostics 2016, 6, 2196-2208. [CrossRef]

95. Li, X.; Zhang, D.; Yin, C.; Lu, G.; Wan, Y.; Huang, Z.; Tan, J.; Li, S.; Luo, J.; Lee, C.-S. A Diradicaloid Small Molecular Nanotheranostic with Strong Near-Infrared Absorbance for Effective Cancer Photoacoustic Imaging and Photothermal Therapy. ACS Appl. Mater. Interfaces 2021, 13, 15983-15991. [CrossRef]

96. Wang, J.-L.; Zhang, L.; Zhao, M.-J.; Zhang, T.; Liu, Y.; Jiang, F.-L. Mitochondria-Targeted BODIPY Nanoparticles for Enhanced Photothermal and Photoacoustic Imaging In Vivo. ACS Appl. Bio Mater. 2021, 4, 1760-1770. [CrossRef]

97. Li, D.; Zhang, Y.; Xu, J.; Yoshino, F.; Xu, H.; Chen, X.; Zhao, L. Surface-Engineered Carbon Nanohorns as a Theranostic Nanodevice for Photoacoustic Imaging and Effective Radiochemotherapy of Cancer. Carbon 2021, 180, 185-196. [CrossRef]

98. Liu, R.; Xu, F.; Wang, L.; Liu, M.; Cao, X.; Shi, X.; Guo, R. Polydopamine-Coated Laponite Nanoplatforms for Photoacoustic Imaging-Guided Chemo-Phototherapy of Breast Cancer. Nanomater. 2021, 11, 394. [CrossRef]

99. Cho, E.C.; Glaus, C.; Chen, J.; Welch, M.J.; Xia, Y. Inorganic Nanoparticle-Based Contrast Agents for Molecular Imaging. Trends Mol. Med. 2010, 16, 561-573. [CrossRef] [PubMed]

100. Li, J.; Arnal, B.; Wei, C.-W.; Shang, J.; Nguyen, T.-M.; O’Donnell, M.; Gao, X. Magneto-Optical Nanoparticles for Cyclic Magnetomotive Photoacoustic Imaging. ACS Nano 2015, 9, 1964-1976. [CrossRef] [PubMed]

101. O'Donnell, M. Magnetic Nanoparticles as Contrast Agents for Molecular Imaging in Medicine. Phys. C Supercond. Appl. 2018, 548, 103-106. [CrossRef]

102. Quyen Chau, N.D.; Ménard-Moyon, C.; Kostarelos, K.; Bianco, A. Multifunctional Carbon Nanomaterial Hybrids for Magnetic Manipulation and Targeting. Biochem. Biophys. Res. Commun. 2015, 468, 454-462. [CrossRef] [PubMed]

103. Yang, M.; Fan, Q.; Zhang, R.; Cheng, K.; Yan, J.; Pan, D.; Ma, X.; Lu, A.; Cheng, Z. Dragon Fruit-like Biocage as an Iron Trapping Nanoplatform for High Efficiency Targeted Cancer Multimodality Imaging. Biomaterials 2015, 69, 30-37. [CrossRef] [PubMed]

104. Wu, B.; Lu, S.-T.; Yu, H.; Liao, R.-F.; Li, H.; Lucie Zafitatsimo, B.V.; Li, Y.-S.; Zhang, Y.; Zhu, X.-L.; Liu, H.-G.; et al. GadoliniumChelate Functionalized Bismuth Nanotheranostic Agent for in Vivo MRI/CT/PAI Imaging-Guided Photothermal Cancer Therapy. Biomaterials 2018, 159, 37-47. [CrossRef]

105. Chang, X.; Zhang, Y.; Xu, P.; Zhang, M.; Wu, H.; Yang, S. Graphene Oxide/MnWO4 Nanocomposite for Magnetic Resonance/Photoacoustic Dual-Model Imaging and Tumor Photothermo-Chemotherapy. Carbon 2018, 138, 397-409. [CrossRef]

106. Voti, R.L.; Leahu, G.; Sibilia, C.; Matassa, R.; Familiari, G.; Cerra, S.; Salamone, T.A.; Fratoddi, I. Photoacoustics for Listening to Metal Nanoparticle Super-Aggregates. Nanoscale Adv. 2021, 3, 4692-4701. [CrossRef]

107. Lamastra, F.R.; Grilli, M.L.; Leahu, G.; Belardini, A.; Li Voti, R.; Sibilia, C.; Salvatori, D.; Cacciotti, I.; Nanni, F. Diatom Frustules Decorated with Zinc Oxide Nanoparticles for Enhanced Optical Properties. Nanotechnology 2017, 28, 375704. [CrossRef]

108. Tan, L.; Wan, J.; Guo, W.; Ou, C.; Liu, T.; Fu, C.; Zhang, Q.; Ren, X.; Liang, X.-J.; Ren, J.; et al. Renal-Clearable Quaternary Chalcogenide Nanocrystal for Photoacoustic/Magnetic Resonance Imaging Guided Tumor Photothermal Therapy. Biomaterials 2018, 159, 108-118. [CrossRef]

109. Li, W.; Chen, X. Gold Nanoparticles for Photoacoustic Imaging. Nanomedicine 2015, 10, 299-320. [CrossRef] [PubMed]

110. Lee, S.; Lee, C.; Park, S.; Lim, K.; Kim, S.S.; Kim, J.O.; Lee, E.S.; Oh, K.T.; Choi, H.-G.; Youn, Y.S. Facile Fabrication of Highly Photothermal-Effective Albumin-Assisted Gold Nanoclusters for Treating Breast Cancer. Int. J. Pharm. 2018, 553, 363-374. [CrossRef] [PubMed]

111. Li, W.; Rong, P.; Yang, K.; Huang, P.; Sun, K.; Chen, X. Semimetal Nanomaterials of Antimony as Highly Efficient Agent for Photoacoustic Imaging and Photothermal Therapy. Biomaterials 2015, 45, 18-26. [CrossRef] [PubMed]

112. Hou, M.; Yan, C.; Chen, Z.; Zhao, Q.; Yuan, M.; Xu, Y.; Zhao, B. Multifunctional NIR-Responsive Poly(Vinylpyrrolidone)-Cu-Sb-S Nanotheranostic Agent for Photoacoustic Imaging and Photothermal/Photodynamic Therapy. Acta Biomater. 2018, 74, 334-343. [CrossRef] [PubMed] 
113. Xu, L.; Hong, S.H.; Sun, Y.; Sun, Z.; Shou, K.; Cheng, K.; Chen, H.; Huang, D.; Xu, H.; Cheng, Z. Dual T1 and T2 Weighted Magnetic Resonance Imaging Based on Gd3+ Loaded Bioinspired Melanin Dots. Nanomed. Nanotechnol. Biol. Med. 2018, 14, 1743-1752. [CrossRef] [PubMed]

114. Hong, S.H.; Sun, Y.; Tang, C.; Cheng, K.; Zhang, R.; Fan, Q.; Xu, L.; Huang, D.; Zhao, A.; Cheng, Z. Chelator-Free and Biocompatible Melanin Nanoplatform with Facile-Loading Gadolinium and Copper-64 for Bioimaging. Bioconjug. Chem. 2017, 28, 1925-1930. [CrossRef]

115. Liu, Q.; Qian, Y.; Li, P.; Zhang, S.; Wang, Z.; Liu, J.; Sun, X.; Fulham, M.; Feng, D.; Chen, Z.; et al. The Combined Therapeutic Effects of 131iodine-Labeled Multifunctional Copper Sulfide-Loaded Microspheres in Treating Breast Cancer. Acta Pharm. Sin. B 2018, 8, 371-380. [CrossRef]

116. Shen, S.; Ding, B.; Zhang, S.; Qi, X.; Wang, K.; Tian, J.; Yan, Y.; Ge, Y.; Wu, L. Near-Infrared Light-Responsive Nanoparticles with Thermosensitive Yolk-Shell Structure for Multimodal Imaging and Chemo-Photothermal Therapy of Tumor. Nanomed. Nanotechnol. Biol. Med. 2017, 13, 1607-1616. [CrossRef]

117. Feng, L.; Dong, Z.; Liang, C.; Chen, M.; Tao, D.; Cheng, L.; Yang, K.; Liu, Z. Iridium Nanocrystals Encapsulated Liposomes as Near-Infrared Light Controllable Nanozymes for Enhanced Cancer Radiotherapy. Biomaterials 2018, 181, 81-91. [CrossRef]

118. Tang, Y.; Yang, T.; Wang, Q.; Lv, X.; Song, X.; Ke, H.; Guo, Z.; Huang, X.; Hu, J.; Li, Z.; et al. Albumin-Coordinated Assembly of Clearable Platinum Nanodots for Photo-Induced Cancer Theranostics. Biomaterials 2018, 154, 248-260. [CrossRef]

119. Zhou, B.; Zhao, J.; Qiao, Y.; Wei, Q.; He, J.; Li, W.; Zhong, D.; Ma, F.; Li, Y.; Zhou, M. Simultaneous Multimodal Imaging and Photothermal Therapy via Renal-Clearable Manganese-Doped Copper Sulfide Nanodots. Appl. Mater. Today 2018, 13, 285-297. [CrossRef]

120. Tang, X.; Tan, L.; Shi, K.; Peng, J.; Xiao, Y.; Li, W.; Chen, L.; Yang, Q.; Qian, Z. Gold Nanorods Together with HSP Inhibitor-VER155008 Micelles for Colon Cancer Mild-Temperature Photothermal Therapy. Acta Pharm. Sin. B 2018, 8, 587-601. [CrossRef] [PubMed]

121. Guo, Z.; Chen, M.; Peng, C.; Mo, S.; Shi, C.; Fu, G.; Wen, X.; Zhuang, R.; Su, X.; Liu, T.; et al. PH-Sensitive Radiolabeled and Superfluorinated Ultra-Small Palladium Nanosheet as a High-Performance Multimodal Platform for Tumor Theranostics. Biomaterials 2018, 179, 134-143. [CrossRef]

122. Liang, R.; Liu, L.; He, H.; Chen, Z.; Han, Z.; Luo, Z.; Wu, Z.; Zheng, M.; Ma, Y.; Cai, L. Oxygen-Boosted Immunogenic Photodynamic Therapy with Gold Nanocages@manganese Dioxide to Inhibit Tumor Growth and Metastases. Biomaterials 2018, 177, 149-160. [CrossRef] [PubMed]

123. He, W.; Ai, K.; Jiang, C.; Li, Y.; Song, X.; Lu, L. Plasmonic Titanium Nitride Nanoparticles for in Vivo Photoacoustic Tomography Imaging and Photothermal Cancer Therapy. Biomaterials 2017, 132, 37-47. [CrossRef]

124. Li, Z.; Liu, J.; Hu, Y.; Li, Z.; Fan, X.; Sun, Y.; Besenbacher, F.; Chen, C.; Yu, M. Biocompatible PEGylated Bismuth Nanocrystals: "All-in-One" Theranostic Agent with Triple-Modal Imaging and Efficient in Vivo Photothermal Ablation of Tumors. Biomaterials 2017, 141, 284-295. [CrossRef]

125. Yu, X.; Yang, K.; Chen, X.; Li, W. Black Hollow Silicon Oxide Nanoparticles as Highly Efficient Photothermal Agents in the Second Near-Infrared Window for in Vivo Cancer Therapy. Biomaterials 2017, 143, 120-129. [CrossRef]

126. Zhou, G.; Xiao, H.; Li, X.; Huang, Y.; Song, W.; Song, L.; Chen, M.; Cheng, D.; Shuai, X. Gold Nanocage Decorated PH-Sensitive Micelle for Highly Effective Photothermo-Chemotherapy and Photoacoustic Imaging. Acta Biomater. 2017, 64, 223-236. [CrossRef]

127. Zhang, M.; Kim, H.S.; Jin, T.; Yi, A.; Moon, W.K. Ultrasound-Guided Photoacoustic Imaging for the Selective Detection of EGFR-Expressing Breast Cancer and Lymph Node Metastases. Biomed. Opt. Express 2016, 7, 1920-1931. [CrossRef]

128. Zhang, R.; Cheng, K.; Antaris, A.L.; Ma, X.; Yang, M.; Ramakrishnan, S.; Liu, G.; Lu, A.; Dai, H.; Tian, M.; et al. Hybrid Anisotropic Nanostructures for Dual-Modal Cancer Imaging and Image-Guided Chemo-Thermo Therapies. Biomaterials 2016, 103, 265-277. [CrossRef]

129. Zhong, J.; Yang, S.; Wen, L.; Xing, D. Imaging-Guided Photoacoustic Drug Release and Synergistic Chemo-Photoacoustic Therapy with Paclitaxel-Containing Nanoparticles. J. Control. Release 2016, 226, 77-87. [CrossRef] [PubMed]

130. Chou, S.-W.; Liu, C.-L.; Liu, T.-M.; Shen, Y.-F.; Kuo, L.-C.; Wu, C.-H.; Hsieh, T.-Y.; Wu, P.-C.; Tsai, M.-R.; Yang, C.-C.; et al. Infrared-Active Quadruple Contrast FePt Nanoparticles for Multiple Scale Molecular Imaging. Biomaterials 2016, 85, 54-64. [CrossRef] [PubMed]

131. Bao, T.; Yin, W.; Zheng, X.; Zhang, X.; Yu, J.; Dong, X.; Yong, Y.; Gao, F.; Yan, L.; Gu, Z.; et al. One-Pot Synthesis of PEGylated Plasmonic MoO3-x Hollow Nanospheres for Photoacoustic Imaging Guided Chemo-Photothermal Combinational Therapy of Cancer. Biomaterials 2016, 76, 11-24. [CrossRef] [PubMed]

132. Feng, Q.; Zhang, Y.; Zhang, W.; Shan, X.; Yuan, Y.; Zhang, H.; Hou, L.; Zhang, Z. Tumor-Targeted and Multi-Stimuli Responsive Drug Delivery System for near-Infrared Light Induced Chemo-Phototherapy and Photoacoustic Tomography. Acta Biomater. 2016, 38, 129-142. [CrossRef] [PubMed]

133. Anamaria, O.; Yang, Y.; Feng, T.; Wang, X.; Wu, H.; Li, Y.; Yang, L.; Tang, X.; Mao, H. A Nanocomposite of Au-AgI Core/Shell Dimer as a Dual-Modality Contrast Agent for x-Ray Computed Tomography and Photoacoustic Imaging. Med. Phys. 2016, 43, 589-599.

134. Mallidi, S.; Kim, S.; Karpiouk, A.; Joshi, P.P.; Sokolov, K.; Emelianov, S. Visualization of Molecular Composition and Functionality of Cancer Cells Using Nanoparticle-Augmented Ultrasound-Guided Photoacoustics. Photoacoustics 2015, 3, 26-34. [CrossRef] [PubMed] 
135. Kanazaki, K.; Sano, K.; Makino, A.; Shimizu, Y.; Yamauchi, F.; Ogawa, S.; Ding, N.; Yano, T.; Temma, T.; Ono, M.; et al. Development of Anti-HER2 Fragment Antibody Conjugated to Iron Oxide Nanoparticles for in Vivo HER2-Targeted Photoacoustic Tumor Imaging. Nanomed. Nanotechnol. Biol. Med. 2015, 11, 2051-2060. [CrossRef]

136. Mou, J.; Liu, C.; Li, P.; Chen, Y.; Xu, H.; Wei, C.; Song, L.; Shi, J.; Chen, H. A Facile Synthesis of Versatile Cu2-XS Nanoprobe for Enhanced MRI and Infrared Thermal/Photoacoustic Multimodal Imaging. Biomaterials 2015, 57, 12-21. [CrossRef]

137. Kishimoto, S.; Oshima, N.; Yamamoto, K.; Munasinghe, J.; Ardenkjaer-Larsen, J.H.; Mitchell, J.B.; Choyke, P.L.; Krishna, M.C. Molecular Imaging of Tumor Photoimmunotherapy: Evidence of Photosensitized Tumor Necrosis and Hemodynamic Changes. Free Radic. Biol. Med. 2018, 116, 1-10. [CrossRef]

138. Samykutty, A.; Grizzle, W.E.; Fouts, B.L.; McNally, M.W.; Chuong, P.; Thomas, A.; Chiba, A.; Otali, D.; Woloszynska, A.; Said, N.; et al. Optoacoustic Imaging Identifies Ovarian Cancer Using a Microenvironment Targeted Theranostic Wormhole Mesoporous Silica Nanoparticle. Biomaterials 2018, 182, 114-126. [CrossRef]

139. Haedicke, K.; Brand, C.; Omar, M.; Ntziachristos, V.; Reiner, T.; Grimm, J. Sonophore Labeled RGD: A Targeted Contrast Agent for Optoacoustic Imaging. Photoacoustics 2017, 6, 1-8. [CrossRef] [PubMed]

140. Lin, S.; Shah, A.; Hernández-Gil, J.; Stanziola, A.; Harriss, B.I.; Matsunaga, T.O.; Long, N.; Bamber, J.; Tang, M.-X. Optically and Acoustically Triggerable Sub-Micron Phase-Change Contrast Agents for Enhanced Photoacoustic and Ultrasound Imaging. Photoacoustics 2017, 6, 26-36. [CrossRef] [PubMed]

141. Li, Y.; Liu, G.; Ma, J.; Lin, J.; Lin, H.; Su, G.; Chen, D.; Ye, S.; Chen, X.; Zhu, X.; et al. Chemotherapeutic Drug-Photothermal Agent Co-Self-Assembling Nanoparticles for near-Infrared Fluorescence and Photoacoustic Dual-Modal Imaging-Guided ChemoPhotothermal Synergistic Therapy. J. Control. Release 2017, 258, 95-107. [CrossRef] [PubMed]

142. Wang, G.; Zhang, F.; Tian, R.; Zhang, L.; Fu, G.; Yang, L.; Zhu, L. Nanotubes-Embedded Indocyanine Green-Hyaluronic Acid Nanoparticles for Photoacoustic-Imaging-Guided Phototherapy. ACS Appl. Mater. Interfaces 2016, 8, 5608-5617. [CrossRef]

143. Chen, J.; Liu, C.; Zeng, G.; You, Y.; Wang, H.; Gong, X.; Zheng, R.; Kim, J.; Kim, C.; Song, L. Indocyanine Green Loaded Reduced Graphene Oxide for In Vivo Photoacoustic/Fluorescence Dual-Modality Tumor Imaging. Nanoscale Res. Lett. $2016,11,85$. [CrossRef]

144. Gao, C.; Deng, Z.-J.; Peng, D.; Jin, Y.-S.; Ma, Y.; Li, Y.-Y.; Zhu, Y.-K.; Xi, J.-Z.; Tian, J.; Dai, Z.-F.; et al. Near-Infrared Dye-Loaded Magnetic Nanoparticles as Photoacoustic Contrast Agent for Enhanced Tumor Imaging. Cancer Biol. Med. 2016, 13, 349-359. [CrossRef]

145. Wang, J.; Guo, F.; Yu, M.; Liu, L.; Tan, F.; Yan, R.; Li, N. Rapamycin/DiR Loaded Lipid-Polyaniline Nanoparticles for DualModal Imaging Guided Enhanced Photothermal and Antiangiogenic Combination Therapy. J. Control. Release 2016, 237, 23-34. [CrossRef]

146. Chen, Q.; Liu, X.; Zeng, J.; Cheng, Z.; Liu, Z. Albumin-NIR Dye Self-Assembled Nanoparticles for Photoacoustic PH Imaging and PH-Responsive Photothermal Therapy Effective for Large Tumors. Biomaterials 2016, 98, 23-30. [CrossRef]

147. Zhang, Y.; Chen, W.; Yang, C.; Fan, Q.; Wu, W.; Jiang, X. Enhancing Tumor Penetration and Targeting Using Size-Minimized and Zwitterionic Nanomedicines. J. Control. Release 2016, 237, 115-124. [CrossRef]

148. Song, X.; Zhang, R.; Liang, C.; Chen, Q.; Gong, H.; Liu, Z. Nano-Assemblies of J-Aggregates Based on a NIR Dye as a Multifunctional Drug Carrier for Combination Cancer Therapy. Biomaterials 2015, 57, 84-92. [CrossRef]

149. Beziere, N.; Lozano, N.; Nunes, A.; Salichs, J.; Queiros, D.; Kostarelos, K.; Ntziachristos, V. Dynamic Imaging of PEGylated Indocyanine Green (ICG) Liposomes within the Tumor Microenvironment Using Multi-Spectral Optoacoustic Tomography (MSOT). Biomaterials 2015, 37, 415-424. [CrossRef] [PubMed]

150. Yin, W.; Kimbrough, C.W.; Gomez-Gutierrez, J.G.; Burns, C.T.; Chuong, P.; Grizzle, W.E.; McNally, L.R. Tumor Specific Liposomes Improve Detection of Pancreatic Adenocarcinoma in Vivo Using Optoacoustic Tomography. J. Nanobiotechnol. 2015, 13, 90. [CrossRef] [PubMed]

151. Kimbrough, C.W.; Hudson, S.; Khanal, A.; Egger, M.E.; McNally, L.R. Orthotopic Pancreatic Tumors Detected by Optoacoustic Tomography Using Syndecan-1. J. Surg. Res. 2015, 193, 246-254. [CrossRef] [PubMed]

152. Yang, B.; Lin, H.; Dai, C.; Chen, Y.; Shi, J. "Stepwise Extraction” Strategy-Based Injectable Bioresponsive Composite Implant for Cancer Theranostics. Biomaterials 2018, 166, 38-51. [CrossRef]

153. Zhang, W.; Deng, G.; Li, B.; Zhao, X.; Ji, T.; Song, G.; Xiao, Z.; Cao, Q.; Xiao, J.; Huang, X.; et al. Degradable Rhenium Trioxide Nanocubes with High Localized Surface Plasmon Resonance Absorbance like Gold for Photothermal Theranostics. Biomaterials 2018, 159, 68-81. [CrossRef]

154. Nagaoka, R.; Tabata, T.; Yoshizawa, S.; Umemura, S.; Saijo, Y. Visualization of Murine Lymph Vessels Using Photoacoustic Imaging with Contrast Agents. Photoacoustics 2018, 9, 39-48. [CrossRef]

155. Xu, C.; Chen, F.; Valdovinos, H.F.; Jiang, D.; Goel, S.; Yu, B.; Sun, H.; Barnhart, T.E.; Moon, J.J.; Cai, W. Bacteria-like Mesoporous Silica-Coated Gold Nanorods for Positron Emission Tomography and Photoacoustic Imaging-Guided Chemo-Photothermal Combined Therapy. Biomaterials 2018, 165, 56-65. [CrossRef]

156. Luke, G.P.; Myers, J.N.; Emelianov, S.Y.; Sokolov, K. V Sentinel Lymph Node Biopsy Revisited: Ultrasound-Guided Photoacoustic Detection of Micrometastases Using Molecularly Targeted Plasmonic Nanosensors. Cancer Res. 2014, 74, 5397-5408. [CrossRef]

157. Cheng, X.; Zhou, X.; Xu, J.; Sun, R.; Xia, H.; Ding, J.; Chin, Y.E.; Chai, Z.; Shi, H.; Gao, M. Furin Enzyme and PH Synergistically Triggered Aggregation of Gold Nanoparticles for Activated Photoacoustic Imaging and Photothermal Therapy of Tumors. Anal. Chem. 2021, 93, 9277-9285. [CrossRef] 
158. Xi, L.; Grobmyer, S.R.; Zhou, G.; Qian, W.; Yang, L.; Jiang, H. Molecular Photoacoustic Tomography of Breast Cancer Using Receptor Targeted Magnetic Iron Oxide Nanoparticles as Contrast Agents. J. Biophotonics 2014, 7, 401-409. [CrossRef]

159. Zhou, M.; Ku, G.; Pageon, L.; Li, C. Theranostic Probe for Simultaneous in Vivo Photoacoustic Imaging and Confined Photothermolysis by Pulsed Laser at $1064 \mathrm{Nm}$ in 4T1 Breast Cancer Model. Nanoscale 2014, 6, 15228-15235. [CrossRef] [PubMed]

160. Xiong, J.; Feng, J.; Qiu, L.; Gao, Z.; Li, P.; Pang, L.; Zhang, Z. SDF-1-Loaded PLGA Nanoparticles for the Targeted Photoacoustic Imaging and Photothermal Therapy of Metastatic Lymph Nodes in Tongue Squamous Cell Carcinoma. Int. J. Pharm. 2019, 554, 93-104. [CrossRef] [PubMed]

161. Yao, D.; Wang, Y.; Zou, R.; Bian, K.; Liu, P.; Shen, S.; Yang, W.; Zhang, B.; Wang, D. Molecular Engineered Squaraine Nanoprobe for NIR-II/Photoacoustic Imaging and Photothermal Therapy of Metastatic Breast Cancer. ACS Appl. Mater. Interfaces 2020, 12, 4276-4284. [CrossRef] [PubMed]

162. Zhao, J.; Jin, G.; Weng, G.; Li, J.; Zhu, J.; Zhao, J. Recent Advances in Activatable Fluorescence Imaging Probes for Tumor Imaging. Drug Discov. Today 2017, 22, 1367-1374. [CrossRef] [PubMed]

163. Bouvier-Müller, A.; Ducongé, F. Application of Aptamers for in Vivo Molecular Imaging and Theranostics. Adv. Drug Deliv. Rev. 2018, 134, 94-106. [CrossRef] [PubMed]

164. Yang, Y.; Xu, L.; Zhu, W.; Feng, L.; Liu, J.; Chen, Q.; Dong, Z.; Zhao, J.; Liu, Z.; Chen, M. One-Pot Synthesis of PH-Responsive Charge-Switchable PEGylated Nanoscale Coordination Polymers for Improved Cancer Therapy. Biomaterials 2018, 156, 121-133. [CrossRef] [PubMed]

165. Silva, M.L.S. Lectin-Based Biosensors as Analytical Tools for Clinical Oncology. Cancer Lett. 2018, 436, 63-74. [CrossRef]

166. Zhen, X.; Pu, K.; Jiang, X. Photoacoustic Imaging and Photothermal Therapy of Semiconducting Polymer Nanoparticles: Signal Amplification and Second Near-Infrared Construction. Small 2021, 17, 2004723. [CrossRef]

167. Goh, Y.; Balasundaram, G.; Moothanchery, M.; Attia, A.; Li, X.; Lim, H.Q.; Burton, N.; Qiu, Y.; Putti, T.C.; Chan, C.W.; et al. Multispectral Optoacoustic Tomography in Assessment of Breast Tumor Margins During Breast-Conserving Surgery: A First-inHuman Case Study. Clin. Breast Cancer 2018, 18, e1247-e1250. [CrossRef]

168. Vedantham, S.; Karellas, A. Emerging Breast Imaging Technologies on the Horizon. Semin. Ultrasound, CT MRI 2018, 39, 114-121. [CrossRef] 